\title{
A Comparative Investigation of the Economics of Seawater Desalting Based on Current and Advanced Distillation Concepts
}

\author{
Pinhas Glueckstern Sherman A. Reed
}

\section{OAK RIDGE NATIONAL LABORATORY}




\section{DISCLAIMER}

This report was prepared as an account of work sponsored by an agency of the United States Government. Neither the United States Government nor any agency Thereof, nor any of their employees, makes any warranty, express or implied, or assumes any legal liability or responsibility for the accuracy, completeness, or usefulness of any information, apparatus, product, or process disclosed, or represents that its use would not infringe privately owned rights. Reference herein to any specific commercial product, process, or service by trade name, trademark, manufacturer, or otherwise does not necessarily constitute or imply its endorsement, recommendation, or favoring by the United States Government or any agency thereof. The views and opinions of authors expressed herein do not necessarily state or reflect those of the United States Government or any agency thereof. 


\section{DISCLAIMER}

Portions of this document may be illegible in electronic image products. Images are produced from the best available original document. 
Printed in the United States of America. Available from National Technical Information Service

U.S. Department of Commerce

5285 Port Royal Road, Springfield, Virginia 22161

Price: Printed Copy $\$ 4.50$; Microfiche $\$ 2.25$

This report was prepared as an account of work sponsored by the United States Government. Neither the United States nor the Energy Research and Development Administration/United States Nuclear Regulatory Commission, nor any of their employees, nor any of their contractors, subcontractors, or their employees, makes any warranty, express or implied, or assumes any legal liability or responsibility for the accuracy, completeness or usefulness of any information, apparatus, product or process disclosed, or represents that its use would not infringe privately owned rights. 
Contract No. W-7405-eng-26

Engineering Technology Division

A COMPARATIVE INVESTIGATION OF THE ECONOMICS OF SEAWATER DESALTING BASED ON CURRENT AND ADVANCED DISTILLATION CONCEPTS

Pinhas Glueckstern Sherman A. Reed

Date Published: October 1976

NOTICE: This document contains information of a preliminary nature and was prepared primarily for internal use at the Oak Ridge National Laboratory. It is subject to revision or correction and therefore does not represent a final report.

OAK RIDGE NATIONAL LABORATORY

Oak Ridge, Tennessee 37830

operated by

UNION CARBIDE CORPORATION

for the

ENERGY RESEARCH AND DEVELOPMENT ADMINISTRATION 
THIS PAGE

WAS INTENTIONALLY

LEFT BLANK 


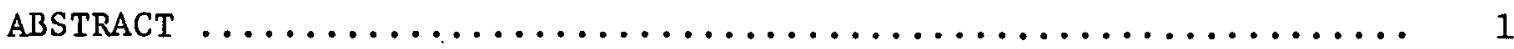

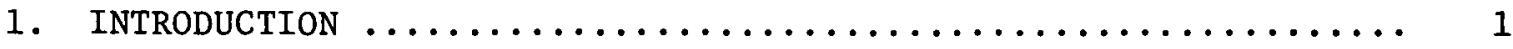

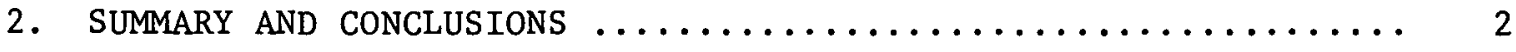

3. SCOPE AND OBJECTIVES OF INVESTIGATION $\ldots \ldots \ldots \ldots \ldots \ldots \ldots \ldots \ldots$

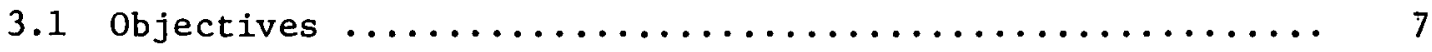

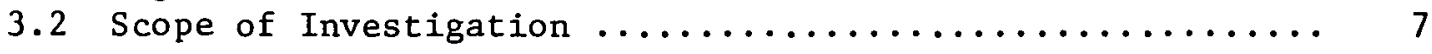

4. EVALUATION METHOD ........................... 8

5. DESALting PlAnt CONCEPTS INVESTigATED $\ldots \ldots \ldots \ldots \ldots \ldots \ldots \ldots$

5.1 General Classification of Current Applied or Proposed

Seawater Desalination Design Concepts ............. 9

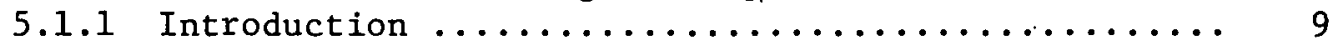

5.1 .2 Multistage flash (MSF) design concepts .......... 9

5.1.3 Multieffect distillation (MED) design concepts .... 10

5.2 Multistage Flash (MSF) Plants .................... 11

5.2 .1 High temperature acid treated plants ........... 11

5.2.2 Low temperature-nonacid treated (threshold)

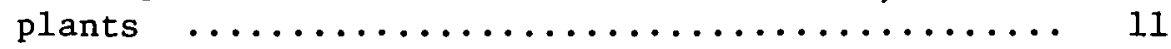

5.3 Vertical Tube Evaporator (VTE) Plants .............. 12

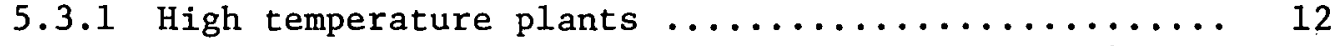

5.3.2 Low-temperature plants applying the $\mathrm{pH}$ control

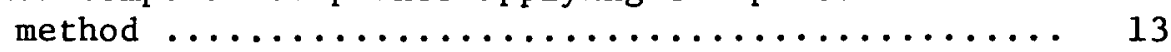

5.3.3 Low-temperature plants applying the threshold pretreatment method .................... 13

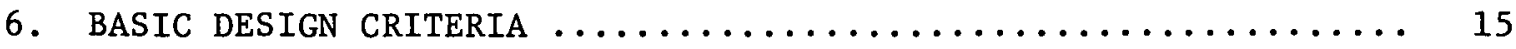

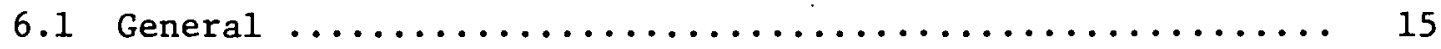

6.2 Summary of Applied Design Criteria $\ldots \ldots \ldots \ldots \ldots \ldots \ldots \ldots$

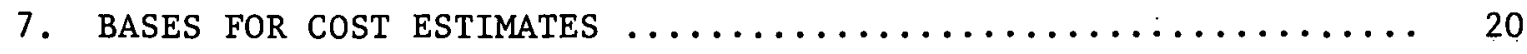

7.1 General and Bases for Direct Capital Cost ............ 20

7.2 Bases for Estimating Indirect Capital, Contingency and

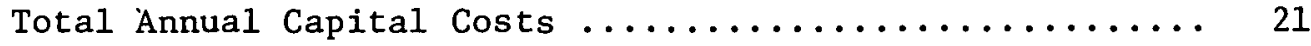

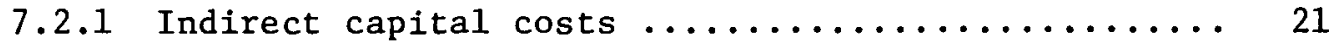

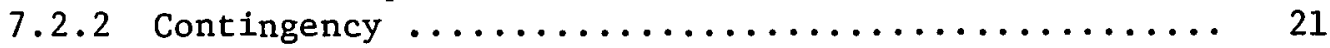

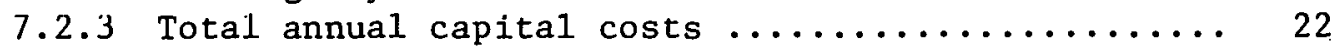

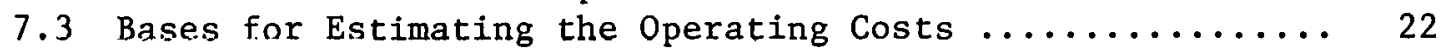

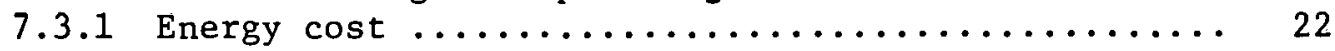

7.3.2 Operation and maintenance labor cost $\ldots \ldots \ldots \ldots . \ldots 23$

7.3.3 Supplies and maintenance naterials ........... 24

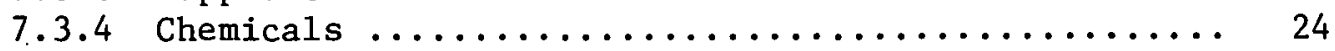

7.4 Summary of Economic Ground Rules and Evaluation of Unit

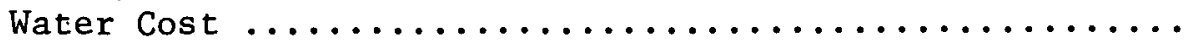


8. DESIGN AND ECONOMIC DATA OF THE OPTIMIZED DESALTING

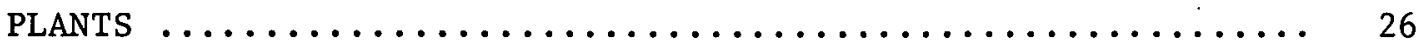

8.1 Optimum Performance Ratio and Typical Design Data ...... 26

8.2 Capital Costs of the Optimized Desalting Plant

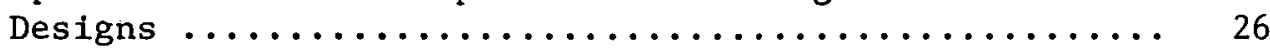

8.3 Unit Water Costs from the Optimized Desalting Plant

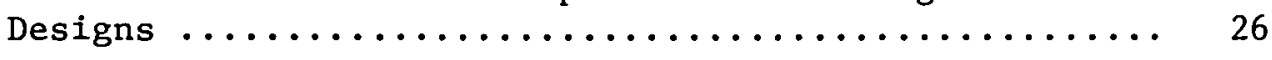

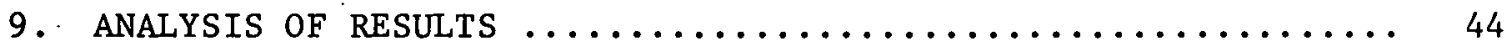

9.1 Range of Capital and Unit Water Costs ............ 44

9.2 Comparison Between High-Temperature MSF and VTE

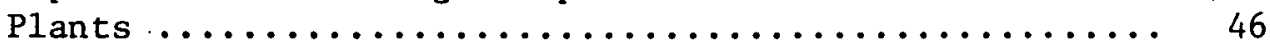

9.3 Comparison Between High- and Low-Temperature MSF

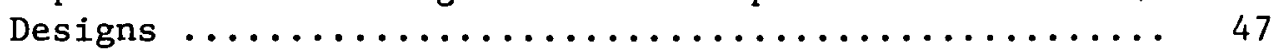

9.4 Comparison Between High- and Low-Temperature VTE Designs ............................... 47

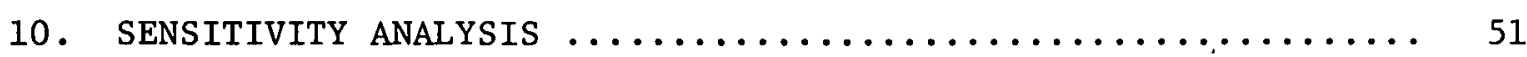

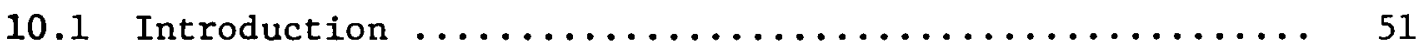

10.2 Effect of Technological Parameters .............. 51

10.3 Effect of Economic Parameters ................. 53

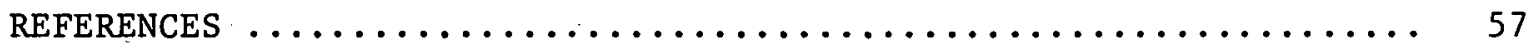


A COMPARATIVE INVESTIGATION OF THE ECONOMICS OF SEAWATER DESALTING BASED ON CURRENT AND ADVANCED DISTILLATION CONCEPTS

\author{
Pinhas Glueckstern * Sherman A. Reed
}

\title{
ABSTRACT
}

\begin{abstract}
A reassessment of desalting plant design and product water cost based on current technology and energy and equipment costs has been made. Plant sizes in the range of 1 to $200 \mathrm{Mgd}$ utilizing the multistage flash (MSF) and the vertical tube evaporator (VTE) were investigated. Process steam was assumed to be supplied by large nuclear dual-purpose plants or from fossil-fired low-pressure boilers. Plants applying the $\mathrm{pH}$ control method versus the threshold pretreatment method were compared. The potential benefits of applying low cost aluminum tubing in low-temperature VTE plants were also investigated.
\end{abstract}

\section{INTRODUCTION}

This document summarizes the recent work performed at Oak Ridge National Laboratory (ORNL) to reevaluate the cost of desalting seawater by applying current technology and cost data as of mid 1975 .

For the two most common desalting processes - the multistage flash evaporator (MSF) and the vertical tube multieffect evaporator (VTE) various tubing materials have been investigated.

For the MSF process, the investigation included a comparison between plants applying the $\mathrm{pH}$ control feedwater pretreatment method and plants operating at lower temperatures applying threshold scale control method by adding to the feedwater makeup small amounts of polyphosphates.

For the VTE process, copper alloy-tubed plants operating at high temperature of $121^{\circ} \mathrm{C}\left(250^{\circ} \mathrm{F}\right)$ were compared with low temperature plants $77^{\circ} \mathrm{C}\left(170^{\circ} \mathrm{F}\right)$ utilizing aluminum alloy tubes either smooth or fluted on the condensing (outside) side. We assumed pH control water pretreatment for plants employing double fluted tubes and polyphosphate pretreatment for plants with semifluted (outside only) tubes.

*Currently Head of the Desalting Department, Mekoroth Water Company, Tel Aviv, Israel. 
All desalting plant designs investigated in the size range of 5 to $200 \mathrm{Mgd}$ were optimized with the aid of the computer programs previously developed at ORNL. This was done after making some changes to the latest versions of the MSF and VTE computer programs. These programs, termed MSF-21 and VTE-21, were modified to apply current technology, instead of the more advanced - and not yet proven - technology adapted in the conceptual designs defined by the initial programs.

In addition to the design modifications, all cost functions have been updated; some of them were escalated to mid-1975 prices and other changes incorporated even more recent cost data (fourth quarter 19.75). The section of the computer program dealing with the evaluation of indirect cost was also modified to include escalation during construction.

\section{SUMMARY AND CONCLUSIONS}

The main objectives of the present study were: (I) to reassess the capital cost and unit water cost of desalting plants applying current technology and cost data, (2) to compare high-temperature plants versus low temperature plants applying threshold feedwater treatment instead of acid, and/or low cost materials, such as aluminum for VTE effect tubing, and (3) to classify potential technological improvements and their effect on capital and unit water costs.

The study considered the following plant types:

1. High temperature, $121^{\circ} \mathrm{C}\left(250^{\circ} \mathrm{F}\right)$, acid-treated MSF plants.

2. Low temperature, $88-93^{\circ} \mathrm{C}\left(190-200^{\circ} \mathrm{F}\right)$, polyphosphate treated MSF plants.

3. High temperature, $121^{\circ} \mathrm{C}\left(250^{\circ} \mathrm{F}\right)$, acid-treated VTE plants.

4. Low temperature, $77^{\circ} \mathrm{C}\left(\sim 170^{\circ} \mathrm{F}\right)$, VTE plants applying aluminum tubing. 'l'his concept could not be based on proven technology and was therefore evaluated for two different subconcepts :

(a) Plants employing doubly-fluted tubes and an acid feedwater pretreatment.

(b) Plants employing tubes fluted only on the condensing side and a threshold feedwater pretreatment. 
The threshold pretreatment method currently uses mainly polyphosphates or polyelectrolytes (recently other additives reported to be more effective have been introduced) at various locations, but mainly for small cross tube MSF plants. As no definite assumption concerning the possible cost savings due to less expensive materials, maintenance, and other cost factors can presently be based on experience, two different sets of assumptions were made, an optimistic and a pessimistic. These sets of assumptions also include different values for the degree of fouling and the corresponding degradation in heat transfer coefficients.

All plant types in slzes ranging between 1 and $200 \mathrm{Mgd}$, using train sizes not larger than $12.5 \mathrm{Mgd}$, were optimized on the basis of the following economic ground rules:

1. Interest rate: $10 \%$

2. Plant operating factor; $85 \%$

3. Plant lifetime: 30 years

4. Energy cost: four price levels based upon:

(a) Process steam and electrical power obtained from large nuclear power reactors. For this nuclear dual-purpose plant version, the estimated energy costs were as follows:

- Process steam at $131^{\circ} \mathrm{C}\left(268^{\circ} \mathrm{F}\right)=\$ 0.50 / 10^{6} \mathrm{Btu}$ at $81^{\circ} \mathrm{C}\left(178^{\circ} \mathrm{F}\right)=\$ 0.17 / 10^{6} \mathrm{Btu}$

- Ejector steam at $100 \mathrm{psi}$ and $166^{\circ} \mathrm{C}\left(330^{\circ} \mathrm{F}\right)=$ $\$ 0.70 / 10^{6} \mathrm{Btu}$

- Electrical power $\quad=\$ 0.02 / \mathrm{kWhr}$.

(b) Process and ejector steam were assumed to be at a price leve1 $150 \%$ higher than in (a). The corresponding electrical power was set $75 \%$ higher, or $\$ 0.035 / \mathrm{kWhr}$. This price level is representative for small nuclear or foesil-fired dual-purpose plants, and/or for the case of a large increase in nuclear fuel and nuclear reactor equipment cost.

(c) Process and ejector steam produced in fossil-fired low-pressure boilers using fuel-oil at a price level 
of $\$ 70$ to $\$ 75 /$ tonne ( $\$ 11$ to $\$ 12 /$ barre1) and electrical power bought at a price of $\$ 0.025 / \mathrm{kWh}$. The corresponding process and ejector steam for this single-purpose plant version at this fuel-oil price was estimated to be $\$ 2 / 10^{6} \mathrm{Btu}$.

(d) Process and ejector steam costs at $\$ 3 / 10^{6}$ Btu $[50 \%$ higher than in (c)].

For the above detailed set of economic ground rules and the prevailing equipment and materials costs in mid-1975, the capital cost per gallon per day and the unit water cost from the optimized desalting plant were as follows:

For dual-purpose plants in the 100 Mgd range: *

\begin{tabular}{|c|c|c|c|}
\hline Plant type & $\begin{array}{c}\text { Performance ratio } \\
1 \mathrm{~b} / 1000 \mathrm{Btu}\end{array}$ & $\begin{array}{c}\text { Capital cost } \\
\text { \$/gpd }\end{array}$ & $\begin{array}{l}\text { Water cost } \\
\$ / 1000 \mathrm{gal}\end{array}$ \\
\hline H1gh-temperature MSF & $10.8-13.6$ & $1.79-2.05$ & $1.33-1.93$ \\
\hline High-temperature VTE & $11.0-13.8$ & $1.54-1.80$ & $1.21-1.79$ \\
\hline $\begin{array}{l}\text { Low-temperature MSF } \\
\text { - threshold optimistic } \\
\text { - threshold pessimistic }\end{array}$ & $\begin{array}{l}7.4-9.4 \\
6.2-7.9\end{array}$ & $\begin{array}{l}1.84-2.12 \\
2.00-2.30\end{array}$ & $\begin{array}{l}1.34-1.92 \\
1.46-2.06\end{array}$ \\
\hline $\begin{array}{l}\text { Low-temperature VTE } \\
\text { (aluminum tubing) } \\
\text { - acid treated } \\
\text { - threshold optimistic } \\
\text { - threshold pessimistic }\end{array}$ & $\begin{array}{l}6.2-7.8 \\
5.4-6.3 \\
5.3-6.2\end{array}$ & $\begin{array}{l}1.54-1.73 \\
1.70-1.80 \\
1.77-1.89\end{array}$ & $\begin{array}{l}1.09-1.51 \\
1.23-1.71 \\
1.28-1.78\end{array}$ \\
\hline
\end{tabular}

For single-purpose plants in the 100-Mgd range:

\begin{tabular}{|c|c|c|c|}
\hline Plant type & $\begin{array}{c}\text { Performance ratio } \\
1 \mathrm{~b} / 1000 \mathrm{Btu}\end{array}$ & $\begin{array}{l}\text { Capital cost } \\
\$ / \text { gpd }\end{array}$ & $\begin{array}{l}\text { Water cost } \\
\$ / 1000 \mathrm{gal}\end{array}$ \\
\hline HIgh-temperature MSF & $15.6-16.0$ & $2.33-2.39$ & $2.31-2.92$ \\
\hline High-temperature VTE & 14.4 & 1.87 & $2.20-2.85$ \\
\hline $\begin{array}{l}\text { Low-temperature MSF } \\
\text { - threshold optimistic } \\
\text { - threshold pessimistic }\end{array}$ & $\begin{array}{l}12.2-14.2 \\
10.8-12.1\end{array}$ & $\begin{array}{l}2.65-3.16 \\
2.98-3.38\end{array}$ & $\begin{array}{l}2.80-3.56 \\
3.16-4.02\end{array}$ \\
\hline $\begin{array}{l}\text { Low-temperature VTE } \\
\text { (aluminum tubing) } \\
\text { - acid treated } \\
\text { - threshold optimistic } \\
\text { - threshold pessimistic }\end{array}$ & $\begin{array}{l}11.8-12.7 \\
11.1-11.9 \\
10.9-11.6\end{array}$ & $\begin{array}{l}2.46-2.65 \\
2.84-3.08 \\
2.96-3.22\end{array}$ & $\begin{array}{l}2.75-3.53 \\
3.09-3.93 \\
3.20-4.12\end{array}$ \\
\hline
\end{tabular}

* Plants with low performance ratios were optimized using energy costs from large nuclear dual-purpose plants. (Refer to pp. 4 and 24.) 
From the results obtained, the following can be concluded regarding desalting costs based upon current technology:

1. For large nuclear dual-purpose plants the optimum performance ratio is in the range of approximately 11 to $14 \mathrm{lb} / 1000 \mathrm{Btu}$. The corresponding capital cost is in the range of $\$ 1.50$ to $\$ 2.00$ per gpd while the unit water cost will range between a low of $\$ 1.20$ per 1000 gallons, for low energy cost, up to approximately $\$ 2.00$ per 1000 gallons for a high energy cost. High-temperature VTE desalting plants have an approximately $15 \%$ lower capital cost and an approximately 10\% lower unit water cost than high-temperature MSF plants. Low-temperature MSF plants applying threshold pretreatment would, at the best, be equal in capital cost and unit water cost to the high temperature MSF plants.

2. For large single-purpose plants the optimum performance ratio for the high temperature plants was set to the assumed limit of $16 \mathrm{lb} / 1000 \mathrm{Btu}$ for the MSF, and $14.4 \mathrm{lb} / 1000 \mathrm{Btu}$ for the VTE for a design utilizing 20 effects with up to 40 preheater stages. The corresponding capital costs ranged from $\$ 1.85$ per gpd for the VTE up to approximately $\$ 2.40$ for the MSF. The unit water costs range from $\$ 2.20$ up to $\$ 2.90$ per 1000 gallons, the VTE having approximately the same economic advantage as the dualpurpose plant. Low temperature MSF plants using threshold pretreatment are less attractive economically for large singlepurpose plants.

3. For small dual-purpose plants (which use bleed steam), in the 1-Mgd range, VTE high temperature plants have no economic advantage over MSF plants. The capital costs for current technology plants ranged between $\$ 3.98$ to $\$ 4.40$ per gpd (see Table 6) and the unit water costs between $\$ 2.85$ to $\$ 4.85$ per 1000 gallons (Table 9). Low temperature MSF plants applying threshold pretreatment were equal in cost or had a small advantage in comparison to the high temperature MSF and VTE plants. 
4. For small single-purpose plants the required capital is very high and might reach $\$ 6.00$ per gpd for low temperature MSF plants. Even for high temperature plants the capital cost is as high as $\$ 5.00$ per gpd and the corresponding unit water cost between $\$ 4.20$ to $\$ 5.00$ per 1000 gallons.

The prevailing high energy and equipment costs point now - more than ever before - to the need for a desalting concept which can apply cheaper construction materials and low-grade energy, such as low-temperature process steam. Multieffect distillation plants, applying vertical or horizontal tubing, are the nearest approaches to those basic requirements. In the present study only the vertical version of this concept has been considered. The potential reduction in unit water cost by applying lowtemperature VTE plants might be as high as 15 to $20 \%$ compared to the best high temperature concept. From the sensitivity analysis performed on a 100-Mgd MSF design, it was found that the total development potential of the MSF process, if fully realized, might reduce unit water costs by about $20 \%$. It was, however, concluded that the assumption of a potential $10 \%$ cost reduction, due to future technological developments, is probably a more realistic figure. 


\section{SCOPE AND OBJECTIVES OF INVESTIGATION}

\subsection{Objectives}

The objectives of the present investigation were as follows:

1. Reassessment of seawater desalting cost by applying the current prevailing technology, equipment, and material cost, at several energy price levels.

2. Appraisal of current applied or proposed desalting plant design concepts in light of the recent changes in energy and equipment costs :

3. Study of $\mathrm{pH}$ control (acid) versus threshold (polyphosphate or other additives) feed treatment for the compared plant types and energy price levels.

\subsection{Scope of Investigation}

All desalting plants investigated were in the range between 1 and $200 \mathrm{Mgd}$. In this range the following sizes were selected: $1,2.5,5$, $12.5,25,50,100$, and $200 \mathrm{Mgd}$. For more detailed analysis only four plant sizes: $1,2.5,12.5$, and $100 \mathrm{Mgd}$ were evaluated.

These plant sizes were optimized for reference heat costs (at $131^{\circ} \mathrm{C}$, $268^{\circ} \mathrm{F}$ ) ranging between $\$ 0.50$ and $\$ 1.25$ per million Btu for dual-purpose plants and two additional heat costs of $\$ 2.00$ and $\$ 3.00$ per million Btu for single-purpose plants. 
4. EVALUATION METHOD

All desalting plant concepts considered (see Sect. 5) were optimized with the aid of ORNL's computer programs MSF21 $1^{1}$ and VTE21.2 These programs, originally developed for rapid optimization of advanced MSF and VTE concepts based upon ORNL's $250 \mathrm{Mgd}$ conceptual designs, 3,4 were modified to allow the evaluation of current technology designs based on prevailing cost and economic criteria. ${ }^{5}$ The adopted design criteria and economic ground rules are detailed in Sects. 6 and 7, respectively.

Each investigated design concept was optimized for four (or more) plant capacities and four different energy cost levels. Although the computer programs are capable of optimizing 8 to 10 of the most important design parameters in the majority of the evaluated designs, only the performance ratio and the number of evaporator stages (MSF) or effects (VTE) were optimized. Other design parameters, such as MSF tube velocities, blowdown to feed concentration ratio and VTE tube length were found to have optimum values beyond the limits set by the adopted design criteria and were therefore set at those limiting design values (see Sect.6). Several additional design parameters, such as the blowdown temperature and the VTE final condenser approach temperature; were optimized for several plant designs, on1y. In a reasonable range of design values these design parameters have only a minor effect on the capital and unit water cost. On the other hand, different design values for the blowdown temperature would yield plant designs with different product water temperatures. Some of them would have to apply product water coolers. For sake of simplicity and easy comparison between the different plant designs, these parameters were kept constant (see Sect. 6).

Because of the above mentioned restrictions in optimizing the design parameters and the obviously limited accuracy of the design and cost models, the results of the designs evaluated should not be considered as fully optimized but rather as reasonable system design configurations. Thus cost estimates are adequate to the scope and objectives of the present study. 


\section{DESALTING PLANT CONCEPTS INVESTIGATED}

\subsection{General Classification of Current Applied or Proposed Seawater Desalination Design Concepts}

\section{1 .1 Introduction}

It is generally accepted that for large seawater desalination plant capacities, especially dual-purpose plants, all possible economical contenders are some version, or subconcepts, of the two basic desalting processes; the multistage flash (MSF) and the multieffect distillation (MED) processes.

The most pronounced differences in the various applied or proposed concepts based on the basic process principles of the MSF and IED are related to the geometric and constructural design of the evaporator tubebundle, the prccess temperature level, the materials of construction (especially the heat transfer tubing), and the feedwater pretreatment method. Some of these differences are not strictly independent, one from the other. Thus, concepts applying a high process temperature level are restricted to materials of construction having adequate strength and corrosion properties at elevated temperatures. The same holds also for the pretreatment method which must be effective at the applied temperature leve1.

Generally, the current applied desalting concepts based on the MSF and MED processes may be classified as follows:

\subsubsection{Multistage flash (MSF) design concepts}

The two structural design concepts are the cross-tube (short tubes) and the long-tube design. Both have advantages and disadvantages at specific conditions. For large capacities the long-tube design was considered to be more economic, especially when applying advanced technology features, such as very long tubes running through a large number of evaporator stages; nearly all conceptual design concepts applied the longtube design. Although this assumption is probably not generally true for plant designs based on current technology, especially for small plant capacitiea, the present evaluation was restricted to the long-tube concept 
because the available computer programs are based on this structural concept.

The two current applied pretreatment methods are the $\mathrm{pH}$ control (mainly applied for high temperature plants) and the threshold, restricted to low temperature plants only.

\subsubsection{Multieffect distillation (MED) design concepts}

The two main structural subconcepts of this process are: the vertical tube evaporator (VTE) and the horizontal tube evaporator (HTE). The main basic differences between these two concepts are related to the characteristics of the heat-transfer mechanism, feed pretreatment and distribution, and the current applied heat-transfer tubing material and geometric shape. The VTE, developed to take full advantage of a high. temperature process, has undergone a number of development stages regarding especially the heat-transfer tubing and the feed preheating. The latest version of this development, applying doubly fluted effect tubing and a MSF evaporator serving as a preheater, was found to be the most economic design concept of the basic MED process applying vertical tubes. The HTE design concept was not found to be competitive with the VTE concept at high process temperature but might have some advantages at lower process temperature where low cost aluminum tubing and the threshold pretreatment can be applied. This concept was extensively developed in Israel where a l-Mgd demonstration plant, built by Israel Desalination Engineering, Ltd., has operated successfully for approximately two years. Presently, a scaled-up version of this concept, having a capacity of 8 to $10 \mathrm{Mgd}$, is in the stages of final design and its construction will start shortly. This desalting plant will be connected to an existing power plant. This project, aimed at developing a prototype of a promising desalting concept, is conducted under a joint development agreement between the United States and the State of Israel and is financed equally by the two countries.

The present study did not consider the HTE concept, especially because of the lack of an appropriate design and cost model of this concept. The potential advantages of a low-temperature MED process, applying aluminum tubing, could however be evaluated for application in a VTE 
design concept, recently proposed and preliminary evaluated by ORNL. ${ }^{6}$ This proposed concept was evaluated and compared to the current technology design concepts. A more detailed discussion of the current technology MSF and VTE concepts which were investigated, as well as that of proposed low temperature VTE utilizing aluminum tubing, is given below.

\subsection{Multistage Flash (MSF) Plants}

\subsubsection{High temperature acid treated plants}

Due to the thermodynamic advantage of high-temperature distillation plants, almost all large desalting plant designs were assumed to operate at the highest possible temperature level, set by the calcium sulphate solubility limit. This maximum temperature is usually set to $121^{\circ} \mathrm{C}$ $\left(250^{\circ} \mathrm{F}\right)$. At this relative high temperature the only proven feedwater pretreatment method is that of $\mathrm{pH}$ control, obtained by acid addition and readjustment (if required) by some neutralizing agent such as $\mathrm{NaOH}$. The other currently applied pretreatment method - the threshold method based on the addition of some sequestering agents such as polyphosphates and polyelectrolytes, are only effective to an upper temperature limit of about 87 to $93^{\circ} \mathrm{C}\left(190\right.$ to $\left.200^{\circ} \mathrm{F}\right)$. Although, as will be discussed later, some recent developed additives were reported to be effective at higher temperatures, the option of applying these additives is still pending more extensive experimental verification.

\subsubsection{Low temperature-nonacid treated (threshold) plants}

Due to the decreased corrosion and operating problems encountered in plants applying this pretreatment method, this concept is usually preferred for plants operating in remote locations short of skilled operating and maintenance staff.

This concept was however not widely considered, until now, for application in large plant capacities because of the already discussed thermodynamic disadvantages. Three recently occurring factors may, however require reconsideration of this concept. These factors were: (a) sharp increase in energy costs, (b) large cost increase in corrosion resistant cladding materials, and (c) development of more efficient 
sequestering agents. The combined effect of using low grade energy in the form of considerable lower turbine extraction steam pressure than required for high temperature processes, and the possible application of cheaper construction materials, may therefore outweigh the inherent thermodynamic disadvantage of the lowntemperature process.

Several uncertainties concerning the economic evaluation of the low temperature threshold pretreatment concept made it necessary, however, to apply various assumptions. These uncertainties are related to design, operational, and costing factors. The most important factor regarding the design is the prediction of the fouling factors. Another design and operational uncertainty is whether the applied threshold pretreatment will require periodic chemical cleaning of the heat transfer tubing. This might affect the investment cost as well as the operating cost. Finally, the potential construction cost saving, compared to an acid pretreatment plant, cannot be estimated accurately without performing a detailed design study of a threshold pretreatment desalting plant.

In order to overcome the above mentioned difficulties occurring in the evaluation of threshold pretreatment plants, the evaluation was made for two sets of assumptions, an optimistic and a pessimistic. The differences in design and operating criteria, in cost assumptions between these two approaches, and in relation to a reference acid pretreatment design, are detailed in sects. 6 and 7 .

\subsection{Vertical Tube Evaporator (VTE) Plants}

\subsubsection{High temperature plants}

The basic advantages of the VTE process, especially applying doubly fluted effect tubes and a MSF preheater, are most pronounced at elevated temperatures. By applying the forward feed method so that the high temperature effects evaporate the less concentrated feed, the problem of calcium sulphate solubility is less than in the MSF process. Thus higher

maximum temperatures and/or blowdown concentrations can be applied. However, due to the higher cost of the required construction materials and of the process steam (in dual-purpose plants) at elevated temperatures, most VTE designs do not utilize top brine temperatures higher than 
121 to $127^{\circ} \mathrm{C}\left(250\right.$ to $260^{\circ} \mathrm{F}$ ), or almost equal to that applied in high temperature MSF designs.

As for the MSF plant designs, the only practical pretreatment method for high temperature VTE designs was found to be the current applied pH control method.

VTE technology has much less operational experience than the more common MSF technology. Moreover, the recent developed concept applying doubly fluted tubes has even less operational experience; and it was therefore difficult to compare VTE versus MSF plants, based on current technology. In order to achieve a reasonable objective and economical comparison between these two basic technologies, a higher contingency allowance was applied in the cost evaluation of the VTE design concepts (see Sect. 7).

\subsubsection{Low-temperature plants applying the $\mathrm{pH}$ control method}

Low-temperature VTE designs were found to be competitive with high temperature plants, or even more economical, when applying low-cost aluminum tubing and a modified $\mathrm{pH}$ control method, termed the "partial-acid" pretreatment method. 6

This proposed pretreatment method requires only about $20 \%$ of the stoichiometric quantity of acid required to reduce the alkalinity to a minimum. This amount of acid, or approximately 20 to $25 \mathrm{ppm}$, would be sufficient to keep the $\mathrm{pH}$ below the threshold at which precipitation would occur.

As the effectiveness of the partial acid feed treatment has yet not been tested, the present study used a more conservative approach in evaluating the potential benefits of aluminum-alloy tubing low-temperature VTE concept, assuming a conventional acid pretreatment by including full neutralization of the alkalinity to elevate the $\mathrm{pH}$ after decarbonation.

\subsubsection{Low-temperature plants applying the threshold pretreatment method}

The threshold pretreatment method has not been tested on vertical tube evaporators with enhanced tubing surfaces. It will be probably much more difficult to remove the "soft" scale or sludge buildup associated with this method from fluted tubes than from smooth surfaces. 
It was therefore concluded that the possible application of semifluted tubes, having enhanced surfaces only on the condensing side, would be a more realistic approach for low-temperature VTE plants applying the threshold method.

Although some experimental tests have been performed to evaluate the overall heat transfer coefficient $(\bar{U})$ of semifluted vertical tubes, ${ }^{7}$ these tests did not include strictly identical conditions of downflow aluminum tubes enhanced on the outside diameter.

From the limited available data only some estimates could be made. The observed $\bar{U}$ for a feed rate of $0.8 \mathrm{gpm}$ [fresh water at $\sim 100^{\circ} \mathrm{C}$ $\left.\left(\sim 212^{\circ} \mathrm{F}\right)\right]$ and a temperature difference $(\Delta \mathrm{T})$ of $6.7^{\circ} \mathrm{C}\left(12^{\circ} \mathrm{F}\right)$, obtained from tests on both semifluted (outside diameter) and doubly fluted 2-in. OD 8-ft-long aluminum tubes, were 920 and $1480 \mathrm{Btu} / \mathrm{hr} \cdot \mathrm{ft}^{2} \cdot{ }^{\circ} \mathrm{F}$, respectively. The corresponding ratio between $\bar{U}$ of $O D$ fluted and a doubly fluted tube was therefore approximately 0.62 . This result can, obviously, be taken only as a rough indication or'estimate.

The present evaluation of VTE design concepts, applying threshold pretreatment, was based on this rough estimate of $\bar{U}$ by multiplying the calculated $\overline{\mathrm{U}}$ for doubly fluted tubes by a factor of 0.6 .

Despite the much lower heat transfer coefficients, it was found still interesting to evaluate VTE design concepts, applying semifluted aluminum alloy tubes, because the results may indicate the economic potential of low-temperature VTE designs, even if an acid pretreatment method cannot be considered compatible with aluminum alloy tubing. Another factor making the evaluation of this design interesting is the fact that the characteristics of this design, such as the average value of the heat transfer coefficient, are very close to those of the aforementloned aluminum alloy horizontal tube evaporator (HTE) design concept.

As for the MSF designs applying the threshold pretreatment, these designs were also evaluated for two sets of assumptions (optimistic and pessimistic). The relevant design and cost assumptions are detailed in Sects. 6 and 7 , respectively. 


\section{BASIC DESIGN CRITERIA}

\subsection{General}

The main objective of this study was to make a reassessment of desalting costs based on current technology. An attempt has therefore been made to use, as far as possible, the same basic design criteria as applied in the recently constructed, or currently designed large desalting plants. These criteria are related mainly to the selection of construction materials and to the feed pretreatment and noncondensable gas removal. The current designed desalting plant designs are usually a much more conservative approach than the various conceptual designs of "advanced" concepts. This approach is probably the result of accumulated operating experience which has indicated the need of a much more corrosion preventative design to reduce the large plant downtimes and high maintenance costs which have been experienced.

As for the thermal-hydraulic design criteria, the values applied in current designs were quite similar to those applied in ORNL's conceptual design. These criteria were tested comprehensively and verified (especially for the MSF) at the San Diego Test Facility.

One of the most important design assumptions was, however, not strictly in accordance with current operating plants. This refers to the applied train and evaporator tube bundle size for large capacity MSF and VTE design. The assumed train sizes of $12.5 \mathrm{Mgd}$ represent a small upscale from current operating large capacity MSF plants ( 8 Mgd at Hong Kong) but a scale down from the MSF prototype tested at the San Diego Test Facility. For the VTE the scale-up, compared to current operating plants ( $\sim 3 \mathrm{Mgd}$ at Orange Counly), is considerably larger but it should be noted that the Orange County plant is a test module employing only 4 effects of a 12-Mgd train. This module could be considered directly applicable to a VTE plant of $12.5-M g d$ capacity.

\subsection{Summary of Applied Design Criteria}

The data for all design concepts are summarized in Table 1 . 
Table 1. Summary of main basic design criteria

\begin{tabular}{|c|c|c|c|c|c|}
\hline Process type & \multicolumn{2}{|c|}{ MSE } & \multicolumn{3}{|c|}{ VTE } \\
\hline Pretreatment & Acid & Threshold & Acid & Acid & Threshold \\
\hline Top brine temperature, ${ }^{\circ} \mathrm{F}$ & 250 & $190-200$ & 250 & 170 & 170 \\
\hline
\end{tabular}

1. Materials of construction

1. Tubing

a. MSF recovery or VTE

preheater

Material

Surface

Tube $O D$, in.

Wall thickness, in.

l.laximum length, ft

b. Brine heater

Material

Tube $O D$, in.

Wall thickness, 1n.

c. Reject section or

final conderser

Material

Tube $O D$, in

Wall chickness, in.

d. VTE effects

Material

Surface

Tube OD, in.

Wall thickness, in.

Tube length, ft

2. Evaporators shell and internals

Shell material

Lining or coating

Brine chambers

Water boxes

Product trays

We1rs

Demisters

3. Seawater intake $\&$ outfall

4. Pumps \& drivers

$90-10$ Cu-N1
smooth
$3 / 4$
0.035
70

$90-10 \mathrm{Cu}-\mathrm{Ni}$
$3 / 4$
0.049

$90-10 \mathrm{Cu}-\mathrm{Ni}$
$3 / 4$

$3 / 4$
0.049
Aluminum-5052

Smooth

$3 / 4$

0.049

Aluminum-5052
$3 / 4$
0.049

uminum-5052

$3 / 4$

$\begin{gathered}\text { Ss sheets } \\ \text { Cu-Ni sheets }\end{gathered}$
316 ss
316 SS
316 SS

Same as in ORNL's conceptual designs

Same, as in ORNL's conceptual designs

\begin{tabular}{lc}
\multicolumn{2}{c}{ Aluminum-5052 } \\
fluted & OD fluted \\
2 & 2 \\
0.050 & 0.050 \\
10 & 10
\end{tabular}

Epoxy or phenolic

\section{SS sheets SS sheets
$\mathrm{Cu}-\mathrm{N} 1$ sheers}

\section{Carbon steel}


Table 1 (continued)

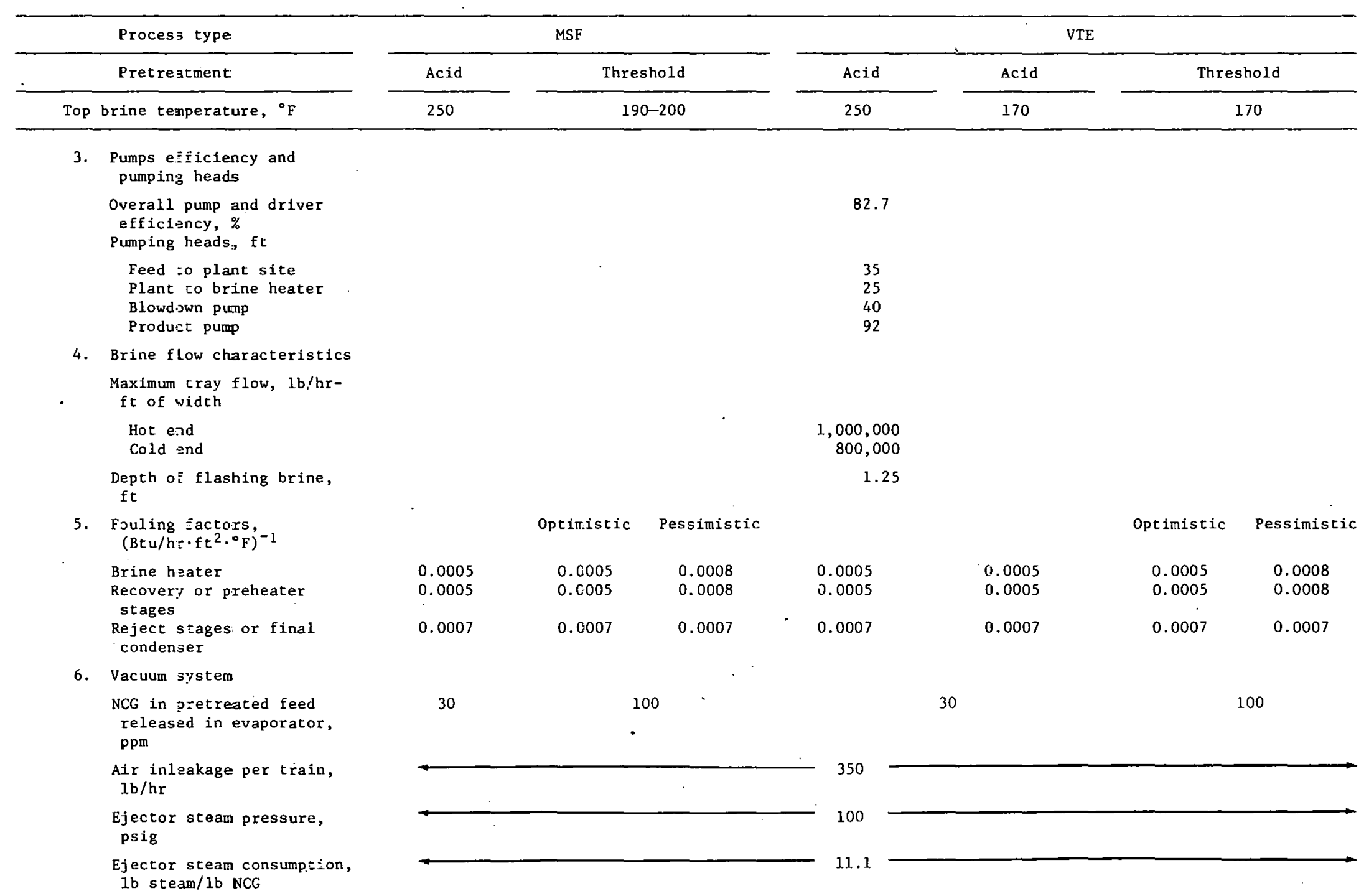


Table 1 (continued)

\begin{tabular}{|c|c|c|c|c|c|c|}
\hline \multirow{2}{*}{\multicolumn{2}{|c|}{ Process type }} & \multicolumn{2}{|r|}{ MSF } & \multicolumn{3}{|c|}{$-\quad$ VTE } \\
\hline & & Acid & Threshold & Acid & Acid & Threshold \\
\hline Top & brine temperature, ${ }^{\circ} \mathrm{F}$ & 250 & $190-200$ & 250 & 170 & 170 \\
\hline \multirow[t]{2}{*}{5.} & $\begin{array}{l}\text { Decarbonator and } \\
\text { deaerator }\end{array}$ & & . & & & \\
\hline & $\begin{array}{l}\text { Decarbonator type } \\
\text { Deaerator type } \\
\text { Shell material } \\
\text { Lining } \\
\text { Packing } \\
\text { Nozzles }\end{array}$ & Atmospheric & Packe & $\begin{array}{c}\text { A } \\
\text { ed bed - external v } \\
\text { Carbon stee } \\
\text { F1berglass } \\
\text { Polypropyle } \\
316 \text { stainless }\end{array}$ & (um) & * \\
\hline 6. & $\begin{array}{l}\text { Steam-jet air ejectors } \\
\text { Ejector steam chest and } \\
\text { air chamber } \\
\text { Diffusers and nozzles } \\
\text { Condensers type and } \\
\text { material }\end{array}$ & \multicolumn{5}{|c|}{$\begin{array}{l}\text { Two-stages + hogging; precondenser, inter-condenser, and after-condenser } \\
\text { - Carbon steel or cast iron }\end{array}$} \\
\hline
\end{tabular}

II. Design parameters

-1. Raw seawater

Tem:perature, ${ }^{\circ} \mathrm{F}$ Salinity, ppm TDS

Alkalinity, ppm

2. Design constraints

a Upper limit for performance ratio, $\mathrm{lb} / 10^{3}, \mathrm{Btu}$

b. Upper limit for number of MSF stages or VTE effects

c. Upper limit for blowdown concentration ratio

d. Lower limit for tube velocities, $f t / s$

MSF recovery or VTE preheater MSF reject or VTE

condenser

Limited by number of effects 
Table 1 (continued)

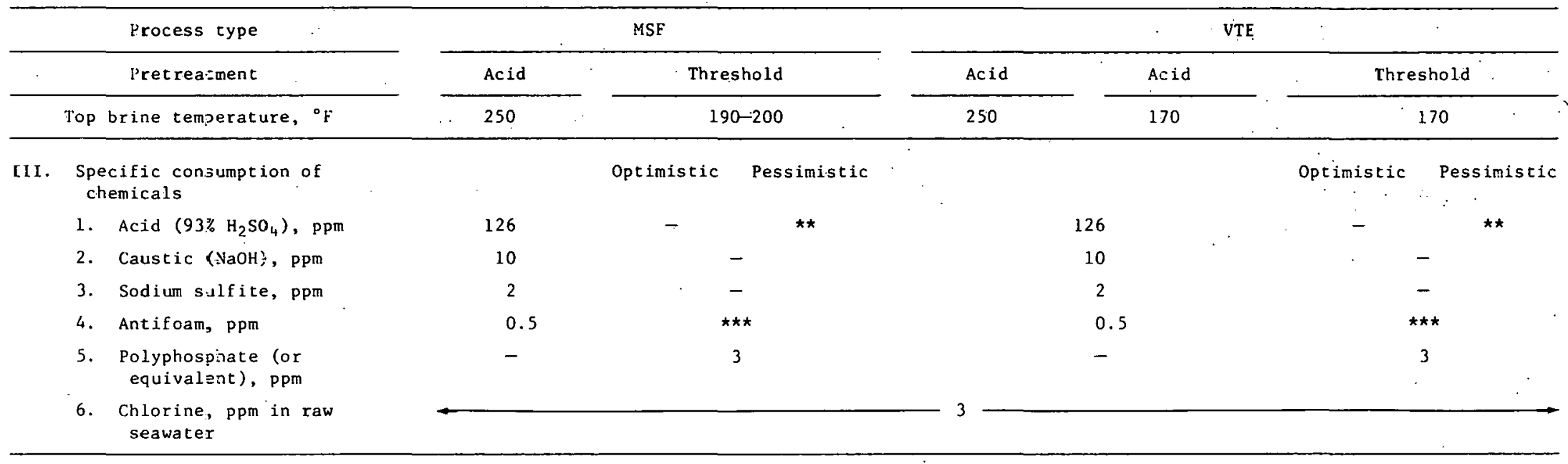

*Fiberglass reinforced polyester made barometric inter- and after-condensers would probably be more economic but no cost data were available.

**Chemical cleaning only.

$\star * \star$ Included in polyphosphate. 


\section{BASES FOR COST ESTIMATES}

\subsection{General and Bases for Direct Capital Cost}

The costs of all design concepts investigated were evaluated with the aid of ORNI's MSF21 and VTE21 computer programs, 1,2 modified and updated to mid-1975 prices. 5 All direct equipment costs, except for heat transfer tubing prices for which current quotations have been used, were escalated to mid-1975 prices by applying the following cost escalation indices:

a. For general construction cost, such as site development, seawater intake and outfall, buildings, and pump pits - the index (construction cost trends) published by the Bureau of Reclamation was used.

b. For process equipment, such as pumps and drivers, piping, valves, instrumentation, vacuum equipment and chemical equipment - the index published by Chemical Engineering (CE plant cost index) was used.

c. For skilled labor cost, such as for installation of tubes and tubesheets, the index published by Engineering News-Record (ENR index) was used.

For nonacid plants (threshold pretreatment) the unit costs for valves, piping, and instrumentation were assumed to be $10 \%$ lower than for acid treated plant. The reduction in evaporator shell cost was assumed to be $20 \%$ lower for the designs based on optimistic assumption and $10 \% 1$ lower for the designs based on pessimistic assumptions. The indirect capital costs, such as engineering and supervision, escalation and interest during construction, owner's costs and contingency, and the total annual capital costs were evaluated in accordance with the applied economic ground rules discussed in Sect. 7.2. All operating costs were estimated on the basis of prevailing manpower and material costs, discussed in Sect. 7.3. 


\subsection{Bases for Estimating Indirect Capital, Contingency and Total Annual Capital Costs}

\subsubsection{Indirect capital costs}

The indirect capital costs were composed of the following components:

a. Engineering, Design, and Supervision (AJSD)

This component was calculated as a function of the direct capital cost, according to the following formula: ${ }^{8}$

AJSD $=1.05+.17582 \exp \left(-2.089 \times 10^{-8} \mathrm{CD}\right)$,

where $C D$ is the total direct cost.

b. Escalation during Construction

This component was evaluated as a function of the estimated construction time, an assumed escalation rate, predicted to be in effect during, the construction time period, and an "S-curve" construction fund expenditure. 5

The construction time, in months, evaluated by ORNL's computer programs $^{8}$ was evaluated according to the following formula: TIME $=54.1 \times\left[1-\left(1.1+6 \times 10^{-9} \mathrm{CD}\right)^{-2.632}\right]$. An annual escalation rate of $8 \%$ was assumed to be in effect during the construction period.

c. Interest during Construction

This component was evaluated, similar to the previous cost item, as a function of construction time and the assumed interest rate. The present evaluation applied an annual interest rate of $10 \%$.

d. Owners Cost for Training and Startup

A value of $1.9 \%$ of all direct and indirect capital costs was assumed for this component.

\subsubsection{Contingency}

This cost component is probably the most disputed, and widely different assumptions have been made in the past by different cost estimators. Obviously, for an accurate cost estimate, without any uncertainties, or for a turnkey project without any owners cost, no contingency would have to be applied. It is generally accepted, however, that the 
assumed allowance for contingency should reflect two main factors, the state of the applied technology (new or proven concept) and the engineering status of the project, i.e. preliminary or detailed design, first or additional identical unit.

In most desalting plant cost estimates, based on preliminary or conceptual designs, a value of 10 to $15 \%$ has been allocated for contingency. These values might have been adequate at financial conditions prevailing several years ago. At the prevailing rate of inflation of equipment cost and high interest rate, it was concluded that a higher contingency allowance should be applied. Thus a value of $25 \%$ was allocated for the MSF design concepts and a value of $30 \%$ for the VTE design concepts based on less extensively proven technology.

\subsubsection{Total annual capital costs}

The total annual capital expenses on the total investment (direct + indirect capital costs + contingency) were calculated by applying the annual fixed charge rate based on the following economic ground rules:

- interest rate: $10 \%$

- sinking fund depreciation rate based on a 30 -year plant 1,ife (0.6\%)

- insurances and taxes: $1 \%$.

This is equivalent to an annual fixed charge rate of $11.6 \%$.

Because of the lack of long-term experience with fluted tubing (especially of aluminum alloys), the VTE effect tubes were conservatively assumed to have a lifetime of 15 years* with a retubing cost, prorated over the total plant lifetime, calculated with the aid of an appropriate costing procedure applied in ORNL's computer programs. 8

\subsection{Bases for Estimating the Operating Costs}

\subsubsection{Energy cost}

The energy costs include those for process steam, ejector steam and electrical-power. Reference energy costs were derived by using current

*This has been the assumed life in all previous ORNL (and other) studies. 
costs for a 1000-MW(e) dual-purpose pressurized water reactor. Fuel cycle costs were based on WASH-1174. The resulting costs for steam at $131^{\circ} \mathrm{C}\left(268^{\circ} \mathrm{F}\right)$ and electricity were $\$ 0.50 / 10^{6} \mathrm{Btu}$ and $\$ 0.020 / \mathrm{kWhr}$. For the steam-jet ejector operating at 100 psig, the resulting steam cost was $\$ 0.70 / 10^{6} \mathrm{Btu}$. The resulting steam costs (SC) for lower steam temperature $\left(\mathrm{T}_{\mathrm{S}}\right)$, as a function of $\mathrm{T}_{\mathrm{s}}$, were fitted by the following polynomial

$$
\left.\mathrm{SC}\left(\mathrm{T}_{\mathrm{s}}\right)=-78.5331+0.644544 \mathrm{~T}_{\mathrm{S}}-0.000608477 \mathrm{~T}_{\mathrm{s}}{ }^{2} \text { (cents } / 10^{6} \mathrm{Btu}\right)
$$

Besides the aforementioned reference energy costs, three additional sets of energy cost were applied, one representing a dual-purpose plant with a $150 \%$ higher extraction steam cost, and two energy price levels corresponding to fossil-fuel-fired single-purpose desalting plants.

The case of high energy cost in a dual-purpose plant was assumed to represent energy price levels prevailing for small nuclear or fossilfired plants, and/or a sharp energy cost increase in large nuclear plants. The corresponding electricity cost was estimated to be $\$ 0.035 / \mathrm{kWhr}$.

The lower energy price level for a single-purpose plant was set to $\$ 2 / 10^{6} \mathrm{Btu}$ for low-pressure steam. This cost corresponds to a fuel-oil price of $\$ 70$ to $\$ 75 /$ tonne ( $\$ 11$ to $\$ 12 /$ barre1). The electric cost at this energy price level was assumed to be $\$ 0.025 / \mathrm{kWhr}$.

The higher energy price level for single-purpose plants was assumed to be $50 \%$ higher for low-pressure steam and $40 \%$ higher for the electricity cost. The resulting costs for low-pressure steam and electricity were, therefore, $\$ 3 / 10^{6}$ Btu and $\$ 0.035 / \mathrm{kWhr}$.

\subsubsection{Operation and mintenance labor cost}

The O\&M labor costs were based on an average man-year cost of $\$ 16,000$ and a $40 \%$ overhead on manpower cost. For a 100-Mgd capacity plant, the total O\&M staff was set to 56 (38 operational and 18 maintenance). For all plant capacities other than $100 \mathrm{Mgd}$, the O\&M labor cost was assumed to have a scale factor of 0.5 . The resulting annual O\&M labor cost (AOMC) in $\$ 10^{3} /$ year as a function of plant capacity (Mgd) was therefore fitted by:

$$
\mathrm{AOMC}(\mathrm{Mgd})=1250(\mathrm{Mgd} / 100) \cdot 5
$$


For nonacid treated plants the O\&M cost was set to $10 \%$ less for the optimistic assumption and the same as for the acid treated plants for the design cases based on pessimistic assumptions.

\subsubsection{Supplies and maintenance materials}

The annual costs for this item was set to $.7 \%$ of the total capital cost for the acid treated.plants and $20 \%$ lower (.56\%) for nonacid treated plants.

\subsubsection{Chemicals}

The annual costs for chemicals were based on the specific consumptions listed in Table 1 and the unit costs of chemicals listed in Table 2.

\subsection{Summary of Economic Ground Rules and Evaluation of Unit Water Cost}

All annual operating costs and the unit water costs were based on a plant operating factor of $85 \%$. A summary of the applied economic ground rules is presented in Table 2 . 
Table 2. Summary of economic ground rules and parameters

\section{General :}

Interest rate, $10 \%$

Insurances and taxes, $1 \%$

Plant operating factor, $85 \%$

Equipment cost basis, mid 1975

Plant life, 30 years

Tubing life:

VTE effect tubes, 15 years

Other tubing, 30 years

Annual escalation of costs during construction, $8 \%$

Contingency, $25 \%$ for MSF and $30 \%$ for VTE designs

O\&M 1abor cost, $\$ 16,000 /$ man-year (average)

General and adminstration cost, $40 \%$ of $0 \& M$ labor cost

Annual costs for supplies and maintenance materials:

Acid-treated plants, $0.7 \%$ of total capital cost

Nonacid plants, $0.56 \%$ of total capital cost

\section{Unit prices of chemicals:}

Sulfuric acid, $\$ 31 /$ ton*

Caustic $(\mathrm{NaOH}), \$ 170 /$ ton

Chlorine, $\$ 176 /$ ton

Antifoam, $\$ 1600 /$ ton

Sodium sulfite, $\$ 305 /$ ton

Polyphosphate, $\$ 3000 /$ ton

\section{Energy costs:}

\begin{tabular}{|c|c|c|c|c|}
\hline \multirow{3}{*}{ Process steam cost, $\$ 10^{6}$ Btwu } & \multicolumn{2}{|c|}{ Dual-purpose } & \multicolumn{2}{|c|}{ Single-purpose } \\
\hline & $\underline{\text { Low }} * *$ & High & $\underline{\text { Low }}$ & High \\
\hline & & & & \\
\hline At 100 psig (for ejectors) & 0.70 & 1.75 & 2.0 & 3.0 \\
\hline At $268^{\circ} \mathrm{F}$ & 0.50 & 1.25 & 2.0 & 3.0 \\
\hline At $178^{\circ} \mathrm{F}$ & 0.17 & 0.425 & 2.0 & 3.0 \\
\hline Electricity, $\$ / \mathrm{kWhr}$ & 0.020 & 0.035 & 0.025 & 0.035 \\
\hline
\end{tabular}

*Bulk, $100 \%$ basis.

**Reference tor large nuclear plañs. 
8. DESIGN AND ECONOMIC DATA OF THE OPTIMIZED DESALTING PLANTS

\subsection{Optimum Performance Ratio and Typical Design Data}

The optimum performance ratios for the various desalting plant concepts investigated, optimized at four energy price levels for small plant capacities ( 1 and $2.5 \mathrm{Mgd}$ ) and large plant capacities (12:5 and $100 \mathrm{Mgd}$ ), are summarized in Tables 3 and 4, respectively.

Typical design data for $100 \mathrm{Mgd}$ (12.5 Mgd train sizes) desalting plants, optimized at the reference energy costs of all design concepts investigated, are listed in Table 5 .

\subsection{Capital Costs of the Optimized Desalting Plant Designs}

The specific investments ( $\$ / g p d)$ for all optimized plant designs, corresponding to the optimum performance ratios listed in Tables 3 and 4, are summarized in Table 6 (small plant capacities) and Table 7 (large plant capacities).

The capital costs for the high-temperature (acid) and low-temperature (threshold) MSF designs versus desalting plant capacity and performance ratio are illustrated in $\mathrm{Fig}$. 1.

The capital costs of the various VTE concepts investigated versus the number of VTE effects $\left(\mathrm{N}_{\mathrm{eff}}\right)$ are illustrated in Fig. 2. The corresponding performance ratio versus $\mathrm{N}_{\text {eff }}$ is also shown on the same figure.

Detailed capital cost breakdowns of the optimized $100 \mathrm{Mgd}$ desalting plant designs listed in Table 5 are presented in Table 8.

\subsection{Unit Water Costs from the Optimized Desalting Plant Designs}

The unit water costs obtained at the reference energy costs from the optimized MSF and VTE desalting plant concepts versus desalting plant capacity are illustrated in Figs. 3 and 4 , respectively.

The unit water costs versus energy costs are listed in Tables 9 and 10, for small and large plant capacities, respectively. The effect of energy cost is also plotted in Fig. 5 (100 Mgd plants) and Fig. 6 (1.0 Mgd plants). 
Table 3. Optimum performance ratio $\left(1 \mathrm{~b} / 10^{3} \mathrm{Btu}\right)$ versus heat cost - small plants (number in brackets $=$ MSF or VTE effects)

\begin{tabular}{|c|c|c|c|c|c|c|c|c|c|c|}
\hline \multirow{3}{*}{ No. } & \multirow{3}{*}{ 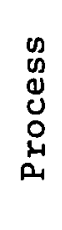 } & \multirow{2}{*}{$\frac{\text { Desalting plant capacity, Mgd }}{\text { Plant type }}$} & \multicolumn{4}{|c|}{1.0} & \multicolumn{4}{|c|}{2.5} \\
\hline & & & \multicolumn{2}{|c|}{ Dual-purpose } & \multicolumn{2}{|c|}{ Single-purpose } & \multicolumn{2}{|c|}{ Dua1-purpose } & \multicolumn{2}{|c|}{ Single-purpose } \\
\hline & & Heat cost, $\$ / 10^{6} \mathrm{Btu}$ & $0.50 *$ & $1.25 *$ & 2.00 & 3.00 & $0.50 *$ & $1.25 *$ & 2.00 & 3.00 \\
\hline 1. & & High temperature (acid) & $\begin{array}{l}(26) \\
8.29\end{array}$ & $\begin{array}{l}(34) \\
11.11\end{array}$ & $\begin{array}{l}(40) \\
13.38\end{array}$ & $\begin{array}{l}(42) \\
13.82\end{array}$ & $\begin{array}{l}(29) \\
9.63\end{array}$ & $\begin{array}{l}(38) \\
12.75\end{array}$ & $\begin{array}{l}(45) \\
13.69\end{array}$ & $\begin{array}{l}(46) \\
16.00\end{array}$ \\
\hline 2. & 䎹. & $\begin{array}{l}\text { Low temperature } \\
(\text { threshold - optimistic) }\end{array}$ & $\begin{array}{l}(20) \\
6.18\end{array}$ & $\begin{array}{l}(24) \\
7.82\end{array}$ & $\begin{array}{l}(31) \\
10.81\end{array}$ & $\begin{array}{l}(33) \\
12.08\end{array}$ & $\begin{array}{l}(20) \\
6.92\end{array}$ & $\begin{array}{l}(25) \\
8.83\end{array}$ & $\begin{array}{l}(32) \\
12.06\end{array}$ & $\begin{array}{l}(34) \\
13.36\end{array}$ \\
\hline 3. & & $\begin{array}{l}\text { Low temperature } \\
\text { (threshold - pessimistic) }\end{array}$ & $\begin{array}{l}(17) \\
5.46\end{array}$ & $\begin{array}{l}(21) \\
6.90\end{array}$ & $\begin{array}{l}(27) \\
9.88\end{array}$ & $\begin{array}{l}(30) \\
11.08\end{array}$ & $\begin{array}{l}(18) \\
5.88\end{array}$ & $\begin{array}{l}(22) \\
7.43\end{array}$ & $\begin{array}{l}(28) \\
10.62\end{array}$ & $\begin{array}{l}(31) \\
11.83\end{array}$ \\
\hline 4. & & $\begin{array}{l}\text { High temperature (acid) } \\
\text { (doubly fluted } \mathrm{Cu}-\mathrm{Ni} \text { tubes) }\end{array}$ & $\begin{array}{l}(15) \\
8.95\end{array}$ & $\begin{array}{l}(17) \\
9.91\end{array}$ & $\begin{array}{l}(20) \\
11.55\end{array}$ & $\begin{array}{l}(20) \\
11.55\end{array}$ & $\begin{array}{l}(15) \\
9.43\end{array}$ & $\begin{array}{l}(19) \\
12.20\end{array}$ & $\begin{array}{l}(20) \\
12.76\end{array}$ & $\begin{array}{l}(20) \\
12.76\end{array}$ \\
\hline 5 . & & $\begin{array}{l}\text { Low temperature (acidi } \\
\text { (doubly fluted aluminum tubes) }\end{array}$ & $\begin{array}{l}(7) \\
5.36\end{array}$ & $\begin{array}{l}(8) \\
5.94\end{array}$ & $\begin{array}{l}(13) \\
9.82\end{array}$ & $\begin{array}{l}(15) \\
10.88\end{array}$ & $\begin{array}{l}(7) \\
5.63\end{array}$ & $\begin{array}{l}(9) \\
7.17\end{array}$ & $\begin{array}{l}(14) \\
10.89\end{array}$ & $\begin{array}{l}(15) \\
11.67\end{array}$ \\
\hline 6. & $\stackrel{10}{-5}$ & $\begin{array}{l}\text { Low temperature (threshold) } \\
\text { (OD fluted aluminum tubes - } \\
\text { op timistic) }\end{array}$ & $\begin{array}{l}(6) \\
4.66\end{array}$ & $\begin{array}{l}(7) \\
5.44\end{array}$ & $\begin{array}{l}(13) \\
9.58\end{array}$ & $\begin{array}{l}(14) \\
10.25\end{array}$ & $\begin{array}{l}(6) \\
4.93\end{array}$ & $\begin{array}{l}(7) \\
5.63\end{array}$ & $\begin{array}{l}(13) \\
10.04\end{array}$ & $\begin{array}{l}(14) \\
10.74\end{array}$ \\
\hline 7. & & $\begin{array}{l}\text { Low temperature (threshold) } \\
\text { (0D fluted aluminum tubes - } \\
\text { pessimistic) }\end{array}$ & $\begin{array}{l}(6) \\
4.49\end{array}$ & $\begin{array}{l}(7) \\
5.24\end{array}$ & $\begin{array}{l}(13) \\
9.19\end{array}$ & $\begin{array}{l}(14) \\
9.84\end{array}$ & $\begin{array}{l}(6) \\
4.79\end{array}$ & $\begin{array}{l}(7) \\
5.45\end{array}$ & $\begin{array}{l}(13) \\
9.68\end{array}$ & $\begin{array}{l}(14) \\
10.35\end{array}$ \\
\hline
\end{tabular}

*For dual-purpose plants reference steam temperature $=268^{\circ} \mathrm{F}$. 
Table 4. Optimum performance $\left(1 \mathrm{~b} / 10^{3} \mathrm{Btu}\right)$ versus heat cost - large plants (numbers in brackets $=$ MSF stages or VTE effects)

\begin{tabular}{|c|c|c|c|c|c|c|c|c|c|c|}
\hline \multirow{3}{*}{ No. } & \multirow{3}{*}{ 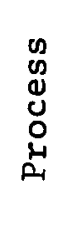 } & \multirow{2}{*}{$\frac{\text { Desalting plant capacity, Mgd }}{\text { Plant type }}$} & \multicolumn{4}{|c|}{12.5} & \multicolumn{4}{|c|}{100.0} \\
\hline & & & \multicolumn{2}{|c|}{ Dual-purpose } & \multicolumn{2}{|c|}{ Single-purpose } & \multicolumn{2}{|c|}{ Dual-purpose } & \multicolumn{2}{|c|}{ Single-purpose } \\
\hline & & Heat cost, $\$ / 10^{6}$ Btu & $0.50 *$ & $1.25 *$ & $\cdot 2.00$ & 3.00 & $0.50 *$ & $1.25 *$ & 2.00 & 3.00 \\
\hline 1. & & High temperature (acid) & $\begin{array}{l}(31) \\
10.66\end{array}$ & $\begin{array}{l}(38) \\
13.53\end{array}$ & $\begin{array}{l}(44) \\
15.69\end{array}$ & $\begin{array}{l}(44) \\
16.00\end{array}$ & $\begin{array}{l}(31) \\
10.71\end{array}$ & $\begin{array}{l}(39) \\
13.52\end{array}$ & $\begin{array}{l}(44) \\
15.62\end{array}$ & $\begin{array}{l}(44) \\
16.00\end{array}$ \\
\hline 2. & 出 & $\begin{array}{l}\text { Low temperature } \\
\text { (threshold - optimistic) }\end{array}$ & $\begin{array}{l}(21) \\
7.39\end{array}$ & $\begin{array}{l}(26) \\
9.42\end{array}$ & $\begin{array}{l}(33) \\
12.15\end{array}$ & $\begin{array}{l}(34) \\
13.51\end{array}$ & $\begin{array}{l}(21) \\
7.38\end{array}$ & $\begin{array}{l}(26) \\
9.44\end{array}$ & $\begin{array}{l}(35) \\
12.17\end{array}$ & $\begin{array}{l}(35) \\
14.17\end{array}$ \\
\hline 3. & & $\begin{array}{l}\text { Low temperature } \\
\text { (threshold - pessimistic) }\end{array}$ & $\begin{array}{l}(18) \\
6.21\end{array}$ & $\begin{array}{l}(22) \\
7.87\end{array}$ & $\begin{array}{l}(28) \\
10.80\end{array}$ & $\begin{array}{l}(31) \\
12.08\end{array}$ & $\begin{array}{l}(18) \\
6.20\end{array}$ & $\begin{array}{l}(22) \\
7.89\end{array}$ & $\begin{array}{l}(28) \\
10.80\end{array}$ & $\begin{array}{l}(31) \\
12.08\end{array}$ \\
\hline 4. & & $\begin{array}{l}\text { High temperature (acid) } \\
\text { (doubly fluted } \mathrm{Cu}-\mathrm{Ni} \text { tubes) }\end{array}$ & $\begin{array}{l}(15) \\
11.00\end{array}$ & $\begin{array}{l}(19) \\
13.75\end{array}$ & $\begin{array}{l}(20) \\
14.38\end{array}$ & $\begin{array}{l}(20) \\
14.38\end{array}$ & $\begin{array}{l}(15) \\
11.00\end{array}$ & $\begin{array}{l}(19) \\
13.75\end{array}$ & $\begin{array}{l}(20) \\
14.38\end{array}$ & $\begin{array}{l}(20) \\
14.38\end{array}$ \\
\hline 5. & & $\begin{array}{l}\text { Low temperature (acid) } \\
\text { (doubly fluted aluminum tubes) }\end{array}$ & $\begin{array}{l}(7) \\
6.18\end{array}$ & $\begin{array}{l}(9) \\
7.83\end{array}$ & $\begin{array}{l}(14) \\
11.84\end{array}$ & $\begin{array}{l}(-15) \\
12.67\end{array}$ & $\begin{array}{l}(7) \\
6.18\end{array}$ & $\begin{array}{l}(9) \\
7.83\end{array}$ & $\begin{array}{l}(14) \\
11: 84\end{array}$ & $\begin{array}{l}(15) \\
12.67\end{array}$ \\
\hline 6. & $\stackrel{5}{S}$ & $\begin{array}{l}\text { Low temperature (threshold) } \\
\text { (OD fluted aluminum tubes- } \\
\text { optimistic) }\end{array}$ & $\begin{array}{l}(6)^{-} \\
5.43\end{array}$ & $\begin{array}{l}(7) \\
6.28\end{array}$ & $\begin{array}{l}(13) \\
11.14\end{array}$ & $\begin{array}{l}(14) \\
11.90\end{array}$ & $\begin{array}{l}(6) \\
5.43\end{array}$ & $\begin{array}{l}(7) \\
6.28\end{array}$ & $\begin{array}{l}(13) \\
11.14\end{array}$ & $\begin{array}{l}(14) \\
11.90\end{array}$ \\
\hline 7. & & $\begin{array}{l}\text { Low temperature (threshold } \\
\text { (OD fluted aluminum tubes - } \\
\text { pessimistic) }\end{array}$ & $\begin{array}{l}(6) \\
5.33\end{array}$ & $\begin{array}{l}(7)^{\circ} \\
6.16\end{array}$ & $\begin{array}{l}(13) \\
10.87\end{array}$ & $\begin{array}{l}.(14) \\
11.62\end{array}$ & $\begin{array}{l}(6) \\
5.33\end{array}$ & $\begin{array}{l}(7) \\
6.16\end{array}$ & $\begin{array}{l}(13) \\
10.87\end{array}$ & $\begin{array}{l}(14)- \\
11.62\end{array}$ \\
\hline
\end{tabular}


Table 5. Design data of optimized $100 \mathrm{Mgd}(12.5 \mathrm{Mgd}$ trains) desalting plants

\begin{tabular}{|c|c|c|c|c|c|c|c|}
\hline \multirow{3}{*}{$\frac{\text { Process type }}{\text { Pretreatment }}$} & \multicolumn{3}{|c|}{ MSF } & \multicolumn{4}{|c|}{ VTE } \\
\hline & \multirow{2}{*}{$\frac{\text { Acid }}{\text { Ref } \in \text { rence }}$} & \multicolumn{2}{|c|}{ Tnreshold } & \multicolumn{2}{|c|}{ Acid } & \multicolumn{2}{|c|}{ Threshold } \\
\hline & & Optimistic & Pessimistic & Reference & $\begin{array}{l}\text { Reference for } \\
\text { aluminum tubing }\end{array}$ & Optimistic & Pessimistic \\
\hline Input steam temperature, ${ }^{\circ} \mathrm{F}$ & 258 & 208 & 198 & 258 & 178 & 178 & 178 \\
\hline Top brine temperature, ${ }^{\circ} \mathrm{F}$ & 250 & 200 & 190 & 250 & 169 & 167 & 167 \\
\hline Performance ratio, $1 \mathrm{~b} / 1000$.BtL & 10.72 & 7.39 & 6.20 & 11.00 & 6.18 & 5.43 & 5.33 \\
\hline $\begin{array}{l}\text { Number of NSF (or VTE } \\
\text { preheater) stages }\end{array}$ & 31 & 21 & 18 & 30 & 14 & 12 & 12 \\
\hline vimber of VTE effects & & & & 15 & 7 & 6 & 6 \\
\hline Total plant length, ft & 557 & 433 & 397 & 222 & 148 & 158 & 158 \\
\hline $\begin{array}{l}\text { Total evaporator } \\
\text { volume, } 10^{3} \mathrm{ft}^{3}\end{array}$ & $2175^{\circ}$ & 2865 & 3016 & 1512 & 2209 & 3507 & 3507 \\
\hline $\begin{array}{l}\text { Average heat transfer coeffi- } \\
\text { cient }(\bar{U}),{ }^{* *} \text { Btu/hr-ft }{ }^{2}-{ }^{\circ} \mathrm{F}\end{array}$ & 600 & 575 & 486 & 1001 & 1046 & 656 & 656 \\
\hline Tubing suriace, ${ }^{\star * *} 10^{3} \mathrm{ft}^{2}$ & 8027 & 8689 & 9097 & 4533 & 4633 & 5841 & 5867 \\
\hline jeawater intake, $10^{6} \mathrm{lb} / \mathrm{hr}$ & 128.8 & 179.5 & 210.8 & 128.8 & 232.1 & 264.2 & 269.2 \\
\hline Total pumping power, MW & 27.70 & 30.64 & 34.33 & 19.48 & 21.50 & 25.91 & 25.91 \\
\hline
\end{tabular}

*At reference energy cost.

**In MSE recovery section or VTE effects.

$* * *$ Including brine heater and final condenser (VTE). 
Table 6. Capital cost of optimized plants versus heat cost - small plants ( $\$ / g p d)$

\begin{tabular}{|c|c|c|c|c|c|c|c|c|c|c|}
\hline \multirow{3}{*}{ No. } & \multirow{3}{*}{ 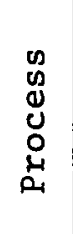 } & \multirow{3}{*}{$\frac{\frac{\text { Desalting plant capacity, Mgd }}{\text { Plant type }}}{\text { Heat cost, } \$ / 10^{6} \mathrm{Btu}}$} & \multicolumn{4}{|c|}{1.0} & \multicolumn{4}{|c|}{2.5} \\
\hline & & & \multicolumn{2}{|c|}{ Dual-purpose } & \multicolumn{2}{|c|}{ Single-purpose } & \multicolumn{2}{|c|}{ Dual-purpose } & \multicolumn{2}{|c|}{ Single-purpose } \\
\hline & & & $0.50 *$ & $1.25 *$ & 2.00 & 3.00 & $0.50 *$ & $1.25 *$ & 2.00 & 3.00 \\
\hline 1. & & High temperature (acid) & 4.40 & 4.86 & 5.39 & 5.48 & 3.00 & 3.42 & 3.56 & 3.98 \\
\hline 2. & $\stackrel{5}{\Sigma}$ & $\begin{array}{l}\text { Low temperature } \\
\text { (threshold - optimistic) }\end{array}$ & 4.05 & 4.56 & 5.51 & 5.99 & 2.98 & 3.31 & 4.08 & 4.48 \\
\hline 3. & & $\begin{array}{l}\text { Low temperature } \\
\text { (threshold - pessimistic) }\end{array}$ & 4.37 & 4.72 & 5.78 & 6.35 & 3.24 & 3.54 & 4.50 & 4.97 \\
\hline 4. & & $\begin{array}{l}\text { High temperature (acid) } \\
\text { (doubly fluted Cu-Ni tubes) }\end{array}$ & 4.11 & 4.39 & 4.76 & 4.76 & 2.76 & 3.13 & 3.23 & 3.23 \\
\hline 5. & & $\begin{array}{l}\text { Low temperature (acid) } \\
\text { (doubly fluted aluminum tubes) }\end{array}$ & 3.78 & 3.99 & 4.95 & 5.45 & 2.72 & 2.93 & 3.81 & 4.04 \\
\hline 6. & 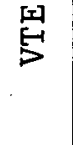 & $\begin{array}{l}\text { Low temperature (threshold) } \\
\text { (OD fluted aluminum tubes - } \\
\text { optimistic) }\end{array}$ & 3.73 & 3.89 & 5.35 & 5.68 & 2.75 & 2.91 & 4.09 & 4.36 \\
\hline 7. & & $\begin{array}{l}\text { Low temperature (threshold) } \\
\text { (OD fluted aluminum tubes - } \\
\text { pessimistic) }\end{array}$ & 3.88 & 4.05 & 5.60 & 5.94 & 2.85 & 3.10 & 4.27 & 4.56 \\
\hline
\end{tabular}

*For dual-purpose plants reference steam temperature $=268^{\circ} \mathrm{F}$. 
Table 7. Capital cost of optimized plants versus heat cost - large plants ( $\$ / g p d)$

\begin{tabular}{|c|c|c|c|c|c|c|c|c|c|c|}
\hline \multirow{3}{*}{ No. } & \multirow{3}{*}{ 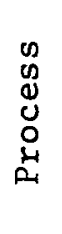 } & \multirow{3}{*}{$\frac{\frac{\text { Desalting plant capaci } \pm y, \text { Mgd }}{\text { Plant type }}}{\text { Teat cost, } \$ 110^{6} \mathrm{Btu}}$} & \multicolumn{4}{|c|}{12.5} & \multicolumn{4}{|c|}{100.0} \\
\hline & & & \multicolumn{2}{|c|}{ Dual-purpose } & \multicolumn{2}{|c|}{ Single-purpose } & \multicolumn{2}{|c|}{ Dual-purpose } & \multicolumn{2}{|c|}{ Single-purpose } \\
\hline & & & $0.50 *$ & $1.25 *$ & 2.00 & 3.00 & $0.50 *$ & $1.25 *$ & 2.00 & 3.00 \\
\hline 1. & & High temperature (acid) & 2.02 & 2.32 & 2.48 & 2.64 & 1.79 & 2.08 & 2.33 & 2.39 \\
\hline 2. & 虹 & $\begin{array}{l}\text { Low temperature } \\
\text { (threshold - optimistic) }\end{array}$ & 2.08 & 2.36 & 2.90 & 3.23 & 1.84 & 2.12 & 2.65 & 3.16 \\
\hline 3. & & $\begin{array}{l}\text { Low temperature } \\
\text { (threshold - pessimistic) }\end{array}$ & 2.26 & 2.55 & 3.26 & 3.66 & 2.00 & 2.30 & 2.98 & 3.38 \\
\hline 4. & & $\begin{array}{l}\text { High temperature (acid) } \\
\text { (doubly fluted Cu-Ni tubes) }\end{array}$ & 1.75 & 2.00 & 2.07 & 2.07 & 1.55 & 1.80 & 2.07 & 2.07 \\
\hline 5. & & $\begin{array}{l}\text { Low temperature (acid) } \\
\text { (doubly fluted aluminum tubes) }\end{array}$ & 1.30 & 1.98 & 2.72 & 2.91 & 1.55 & 1.73 & 2.46 & 2.65 \\
\hline 6. & $\stackrel{9}{S}$ & $\begin{array}{l}\text { Low temperature (threshold) } \\
\text { (OD fluted aluminum tubes - } \\
\text { optimistic) }\end{array}$ & 1.97 & 2.07 & 3.11 & 3.35 & 1.70 & 1.80 & $2: 84$ & 3.08 \\
\hline 7. & & $\begin{array}{l}\text { Low temperature (threshold) } \\
\text { (or fluted aluminum tubes - } \\
\text { pessimistic) }\end{array}$ & 2.05 & 2.16 & 3.25 & 3.51 & 1.77 & 1.89 & 2.97 & 3.23 \\
\hline
\end{tabular}

$\star$ For dual-purpose plants $r \in$ ference steam temperature $=268^{\circ} \mathrm{F}$. 
Table 8. Capttal cost breakdown of optimized (at reference energy cost) 100 Hgd desalting plants

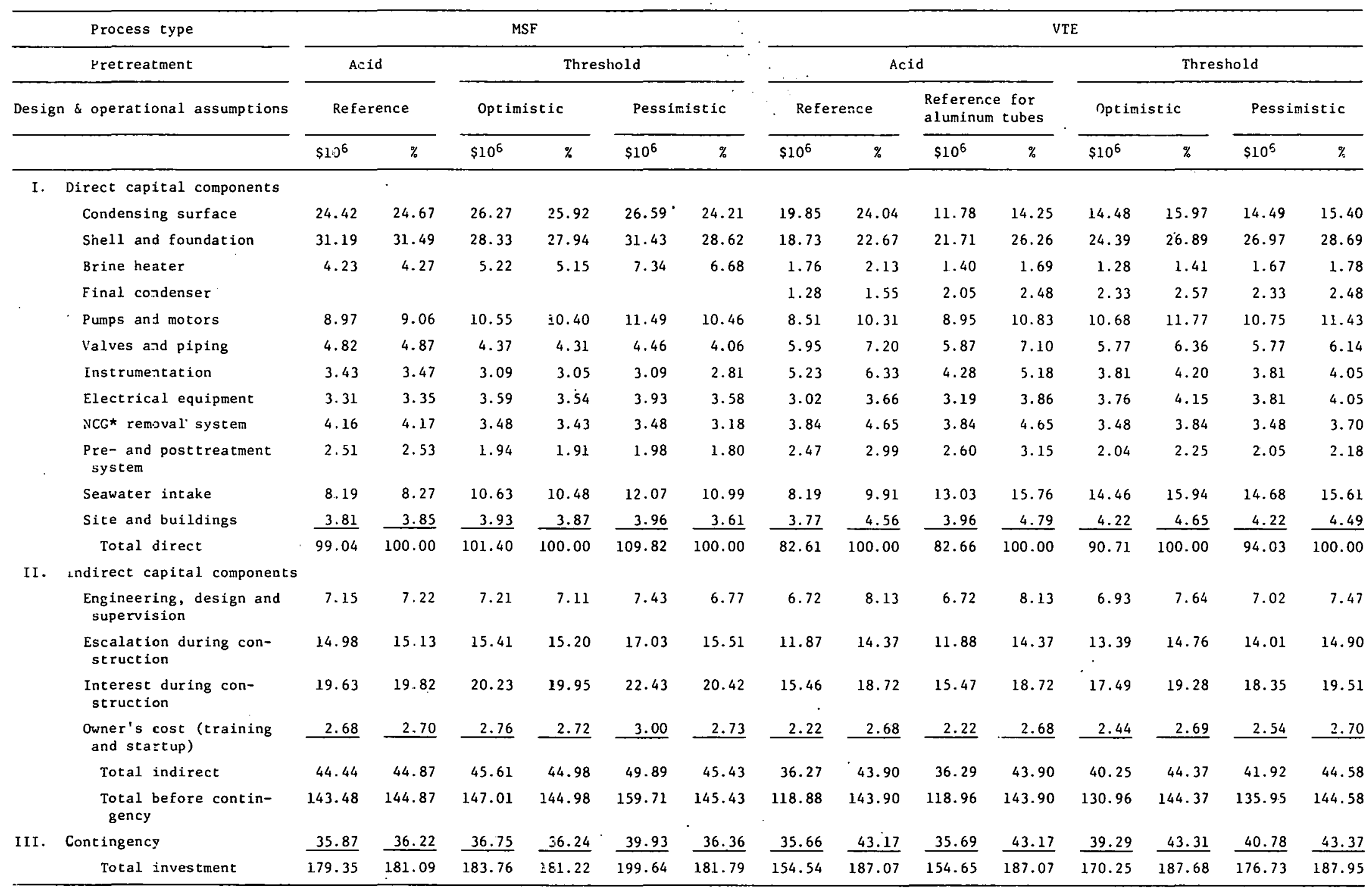

* Noncondensable gas inclucing decarbonator for acid plants. 


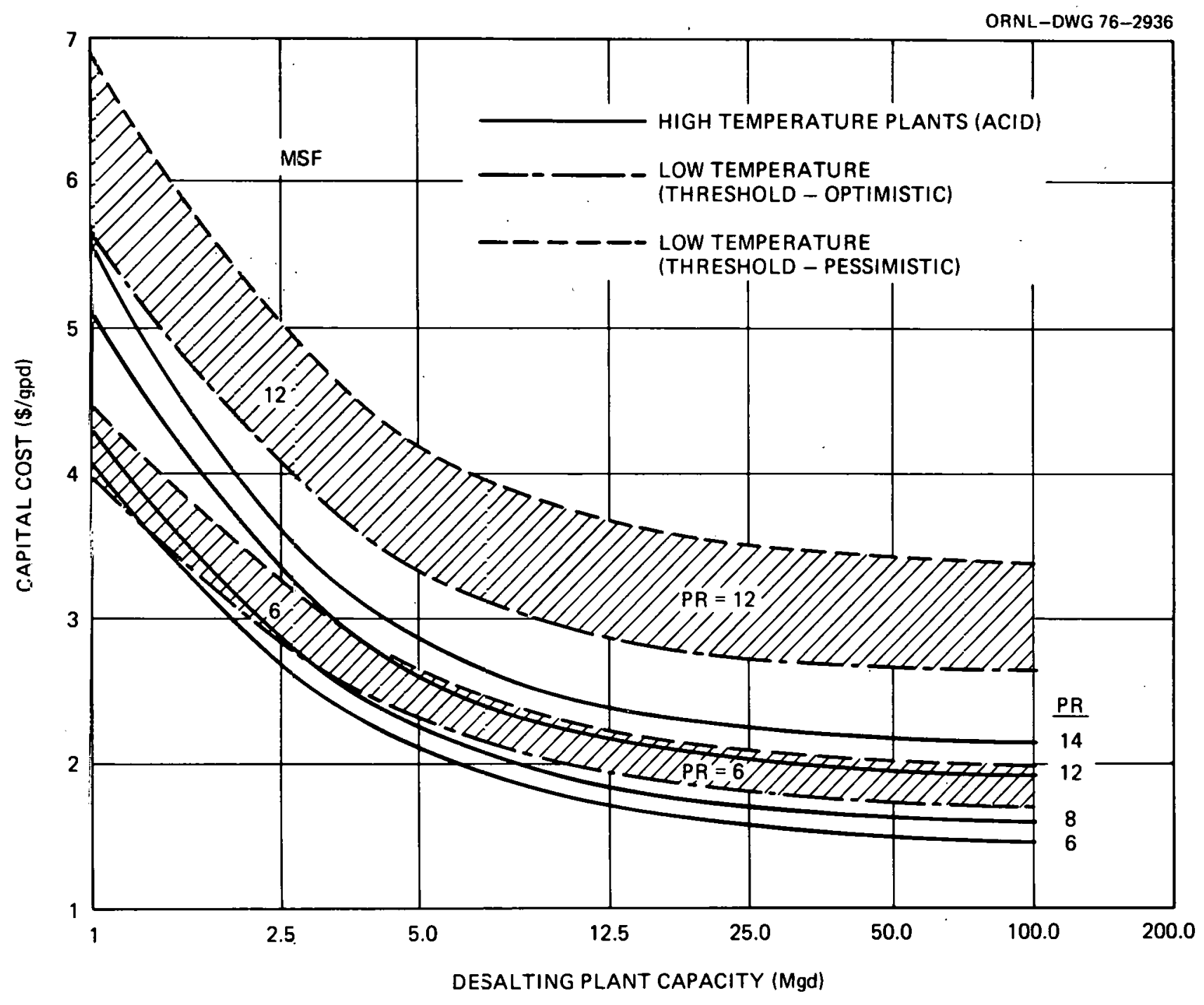

Fig. 1. MSF capital cost vs desalting plant capacity and performance ratio ( $P R$ ). 


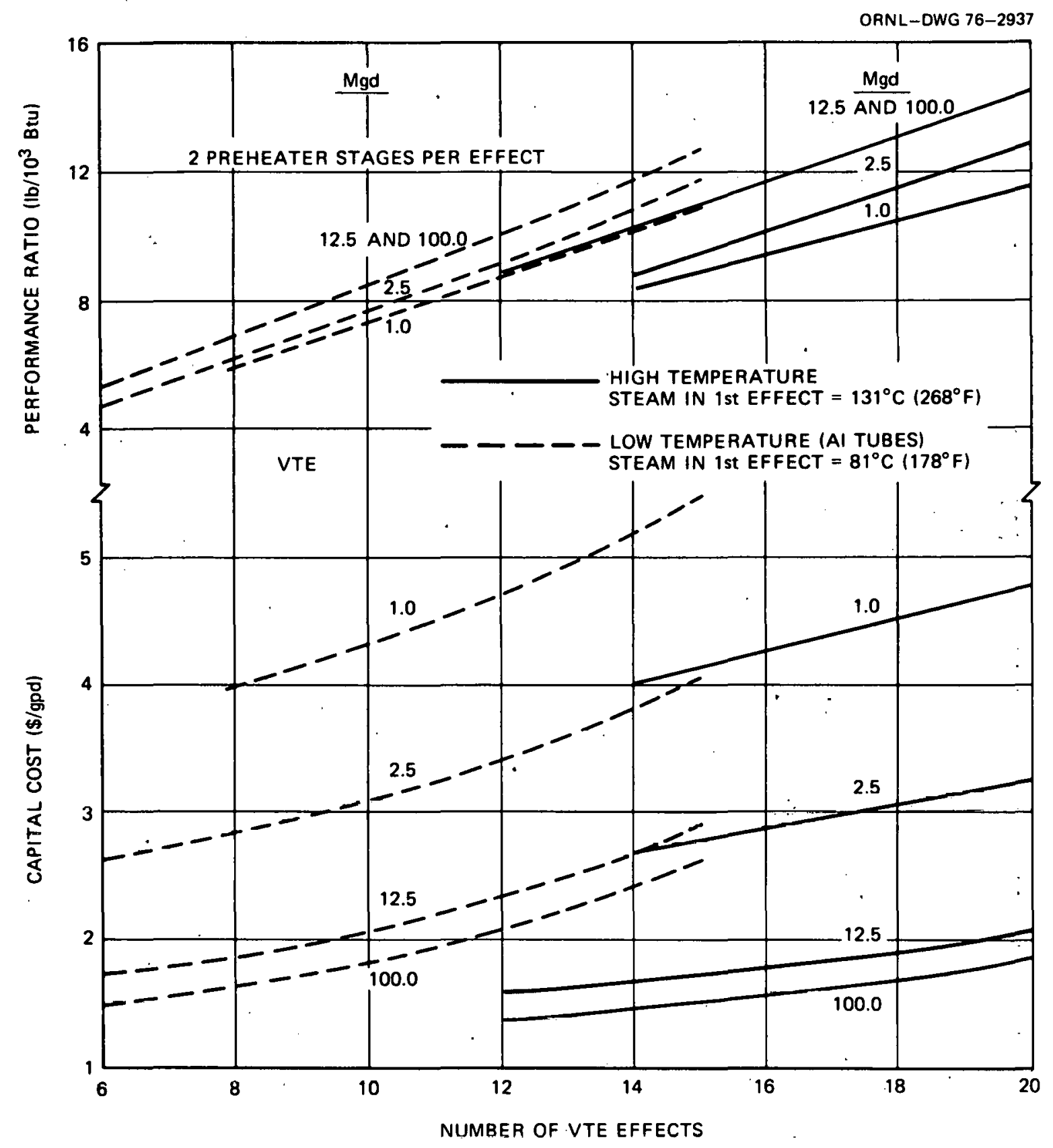

Fig. 2. Performance ratio and capital cost vs number of VTE effects and desalting plant capacity. 


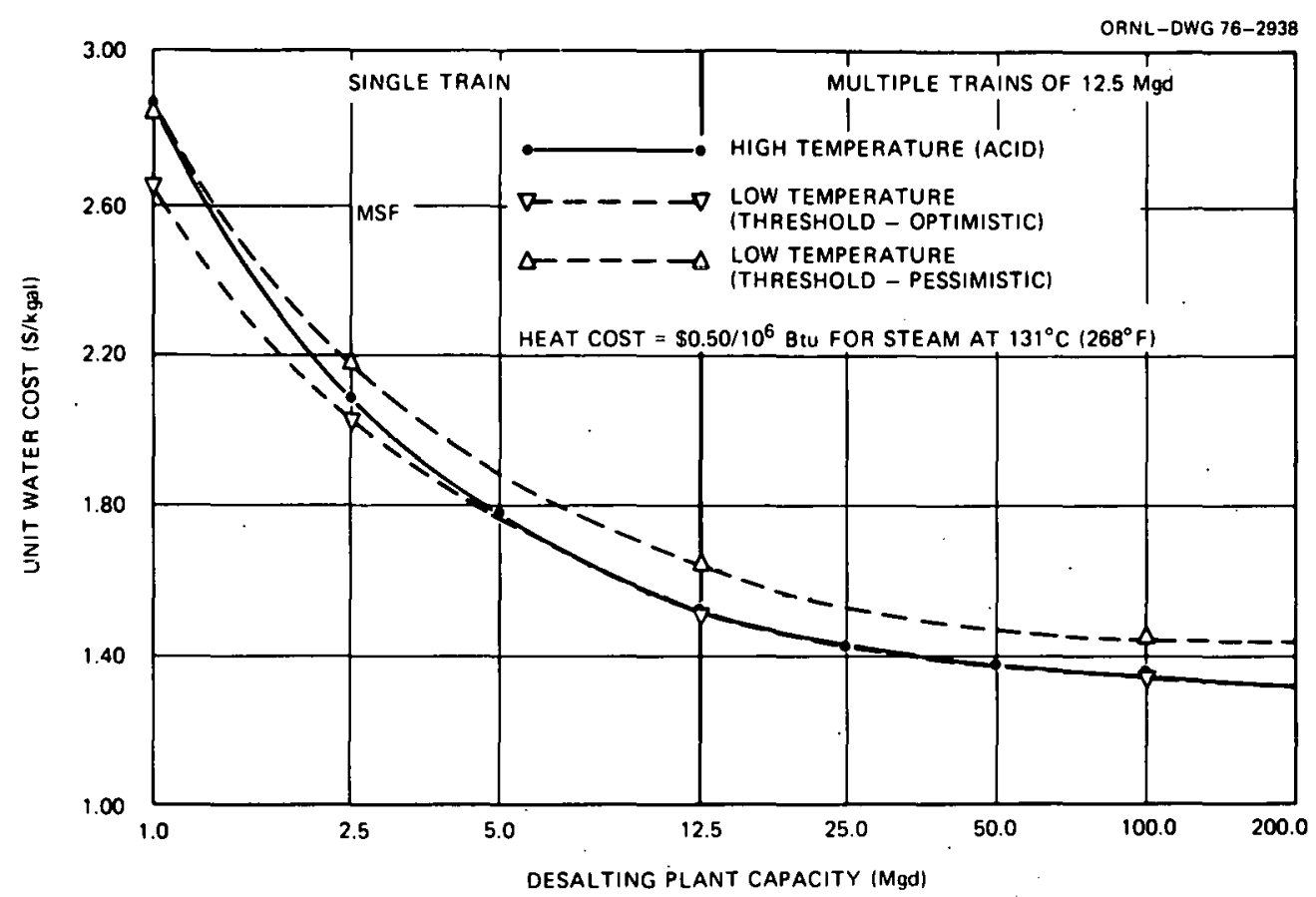

Fig. 3. Unit water cost vs desalting plant capacity (dual-purpose MSF - reference energy cost).

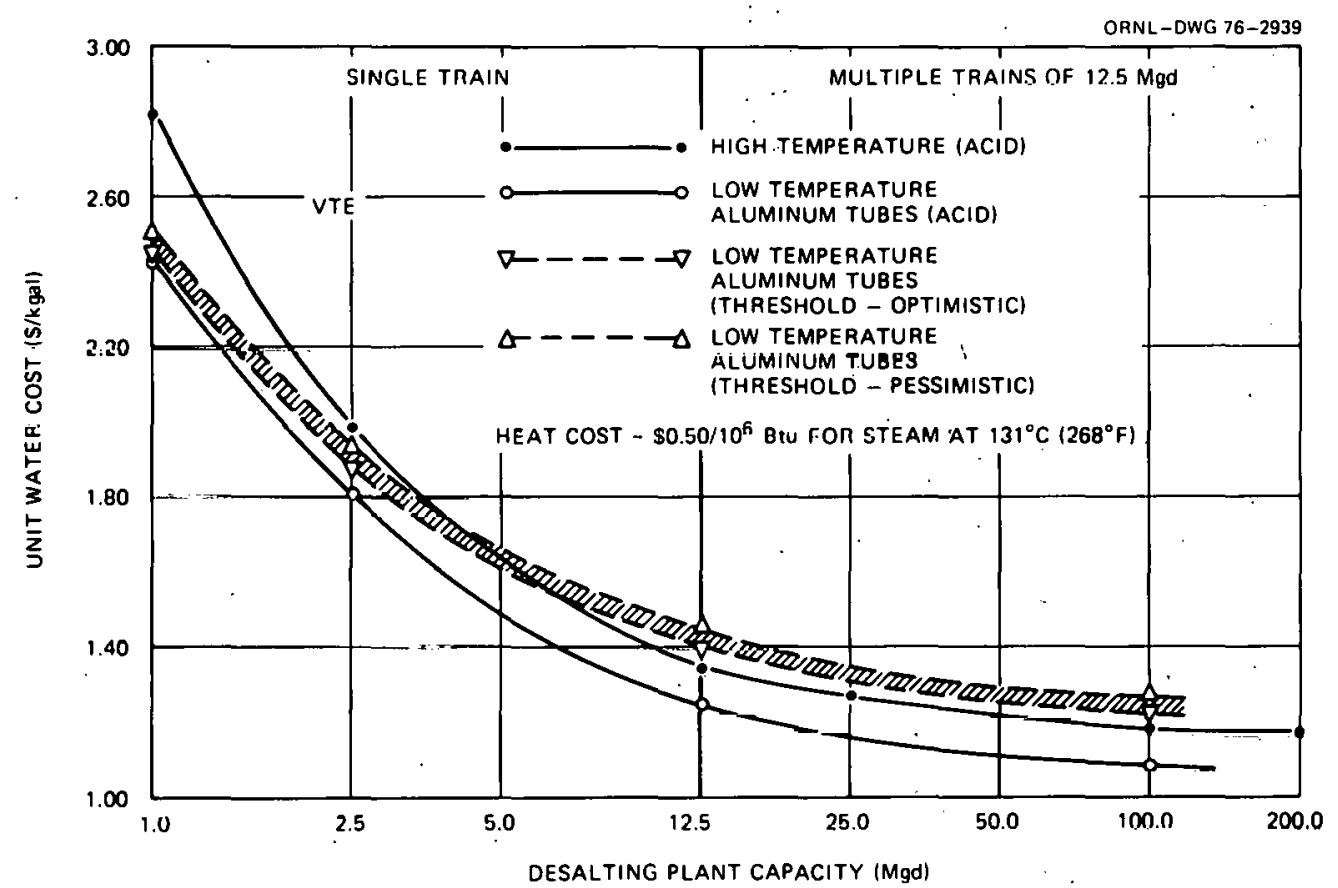

Fig. 4. Unit water cost vs desalting plant capacity (dual-purpose VTE - refcrence energy cost). 
Table 9. Unit water cost from optimized plants versus heat cost - small plants ( $\$ / 1000 \cdot g a 1)$

\begin{tabular}{|c|c|c|c|c|c|c|c|c|c|c|}
\hline \multirow{3}{*}{ No. } & \multirow{3}{*}{ 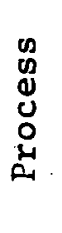 } & \multirow{3}{*}{$\frac{\frac{\text { Desalting plant capacity, Mgd }}{\text { Plant type }}}{\text { Heat } \cos t, \$ 10^{6} \mathrm{Btu}}$} & \multicolumn{4}{|c|}{1.0} & \multicolumn{4}{|c|}{2.5} \\
\hline & & & \multicolumn{2}{|c|}{ Dua1-purpose } & \multicolumn{2}{|c|}{ Single-purpose } & \multicolumn{2}{|c|}{ Dual-purpose } & \multicolumn{2}{|c|}{ Single-purpose } \\
\hline & & & $0.50 *$ & $1.25 *$ & 2.00 & 3.00 & $0.50 *$ & $1.25 *$ & 2.00 & 3.00 \\
\hline 1. & & High temperature (acid) & 2.85 & 3.68 & 4.20 & 4.85 & 2.08 & 2.79 & 3.20 & 3.84 \\
\hline 2. & 戦 & $\begin{array}{l}\text { Low temperature } \\
\text { (threshold - optimistic })\end{array}$ & 2.64 & 3.46 & 4.57 & 5.50 & 2.02 & 2.66 & 3.61 & 4.41 \\
\hline 3. & & $\begin{array}{l}\text { Low temperature } \\
\text { (threshold - pessimistic) }\end{array}$ & 2.84 & 3.58 & 4.99 & 6.00 & 2.19 & 2.84 & 4.04 & 4.95 \\
\hline 4 . & & $\begin{array}{l}\text { High temperature (acid) } \\
\text { (doubly fluted } \mathrm{Cu}-\mathrm{Ni} \text { tubes) }\end{array}$ & 2.72 & 3.58 & 4.14 & 5.00 & 1.98 & 2.65 & 3.14 & 3.89 \\
\hline 5. & & $\begin{array}{l}\text { Low temperature (acid) } \\
\text { (doubly fluted aluminum tubes) }\end{array}$ & 2.43 & 3.04 & 4.51 & 5.52 & 1.80 & 2.27 & 3.66 & 4.53 \\
\hline 6. & $\stackrel{5}{5}$ & $\begin{array}{l}\text { Low temperature (threshold) } \\
\text { (OD fluted aluminum tubes - } \\
\text { optimistic }\end{array}$ & 2.44 & 3.06 & 4.78 & 5.84 & 1.87 & 2.45 & 3.98 & 4.96 \\
\hline 7. & & $\begin{array}{l}\text { Low temperature (threshold) } \\
\text { (OD fluted aluminum tubes - } \\
\text { pessimistic) }\end{array}$ & 2.52 & 3.16 & 5.01 & 6.11 & 1.93 & 2.59 & 4.15 & 5.16 \\
\hline
\end{tabular}

*For dual-purpose plants reference steam temperature $=268^{\circ} \mathrm{F}$. 
Table 10. Unit water cost from optimized plants versus heat cost - large plants ( $\$ 1000$ gal)

\begin{tabular}{|c|c|c|c|c|c|c|c|c|c|c|}
\hline \multirow{3}{*}{ No. } & \multirow{3}{*}{$\begin{array}{l}0 \\
0 \\
0 \\
0 \\
0 \\
01\end{array}$} & \multirow{3}{*}{$\frac{\frac{\text { Desalting plant capacity, Mgd }}{\text { Plant type }}}{\text { Heat cost, } \$ / 10^{6} \mathrm{Btu}}$} & \multicolumn{4}{|c|}{12.5} & \multicolumn{4}{|c|}{100.0} \\
\hline & & & \multicolumn{2}{|c|}{ Dual-purpose } & \multicolumn{2}{|c|}{ Single-purpose } & \multicolumn{2}{|c|}{ Dual-purpose } & \multicolumn{2}{|c|}{ Single-purpose } \\
\hline & & & $0.50 *$ & $1.25 *$ & 2.00 & 3.00 & $0.50 *$ & $1.25 *$ & 2.00 & 3.00 \\
\hline 1. & & High temperature (acid) & 1.50 & 2.10 & 2.49 & 3.10 & 1.33 & 1.93 & 2.31 & 2.93 \\
\hline 2. & 出 & $\begin{array}{l}\text { Low temperature } \\
\text { (threshold - optimistic) }\end{array}$ & 1.51 & 2.08 & 2.96 & 3.73 & 1.34 & 1.92 & 2.80 & 3.56 \\
\hline 3. & & $\begin{array}{l}\text { Low temperature } \\
\text { (threshold - pessimistic) }\end{array}$ & 1.63 & 2.24 & 3.34 & 4.20 & 1.45 & 2.06 & 3.16 & 4.02 \\
\hline 4. & & $\begin{array}{l}\text { High temperature (acid) } \\
\text { (doubly fluted } \mathrm{Cu}-\mathrm{Ni} \text { tubes) }\end{array}$ & 1.36 & 1.93 & 2.35 & 3.00 & 1.20 & 1.78 & 2.20 & 2.85 \\
\hline 5. & & $\begin{array}{l}\text { Low temperature (acid) } \\
\text { (doubly fluted aluminum tubes) }\end{array}$ & 1.26 & 1.68 & 2.93 & 3.80 & 1.09 & 1.50 & 2.75 & 3.53 \\
\hline 6. & 䆥 & $\begin{array}{l}\text { Low temperature (threshold) } \\
\text { (aD fluted aluminum tubes - } \\
\text { optimistic) }\end{array}$ & 1.40 & 1.88 & 3.27 & 4.16 & 1.23 & 1.71 & 3.09 & 3.99 \\
\hline 7. & & $\begin{array}{l}\text { Low temperature (threshold) } \\
\text { (OD fluted aluminum tubes - } \\
\text { pessimistic) }\end{array}$ & 1.47 & 1.96 & 3.39 & 4.30 & 1.28 & 1.78 & 3.20 & 4.12 \\
\hline
\end{tabular}

*For dual-purpose plants reference steam temperature $=268^{\circ} \mathrm{F}$. 


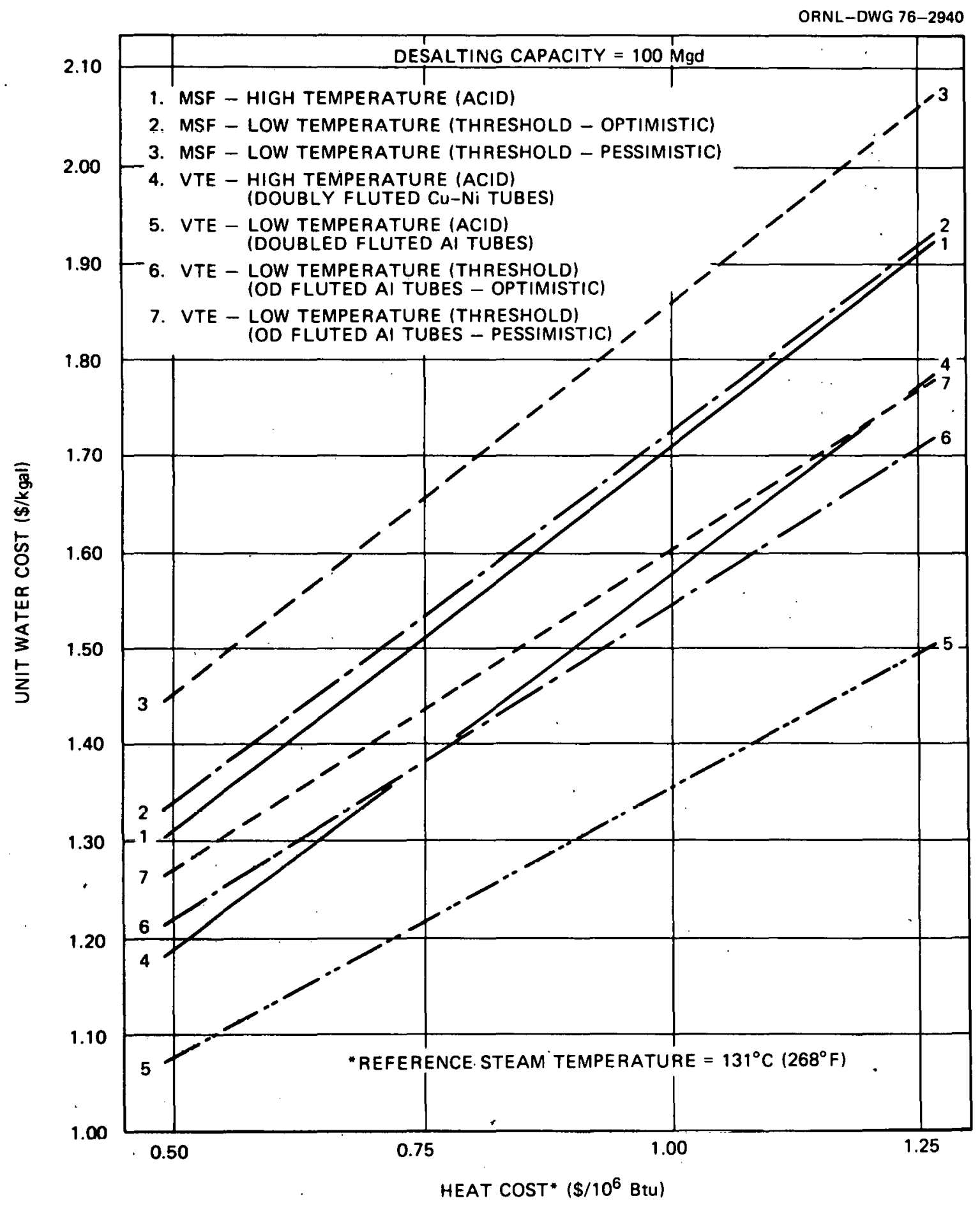

Fig. 5. Unit water cost vs heat cost. Comparison of $100 \mathrm{Mgd}$ MSF and VTE dual-purpose plants. 


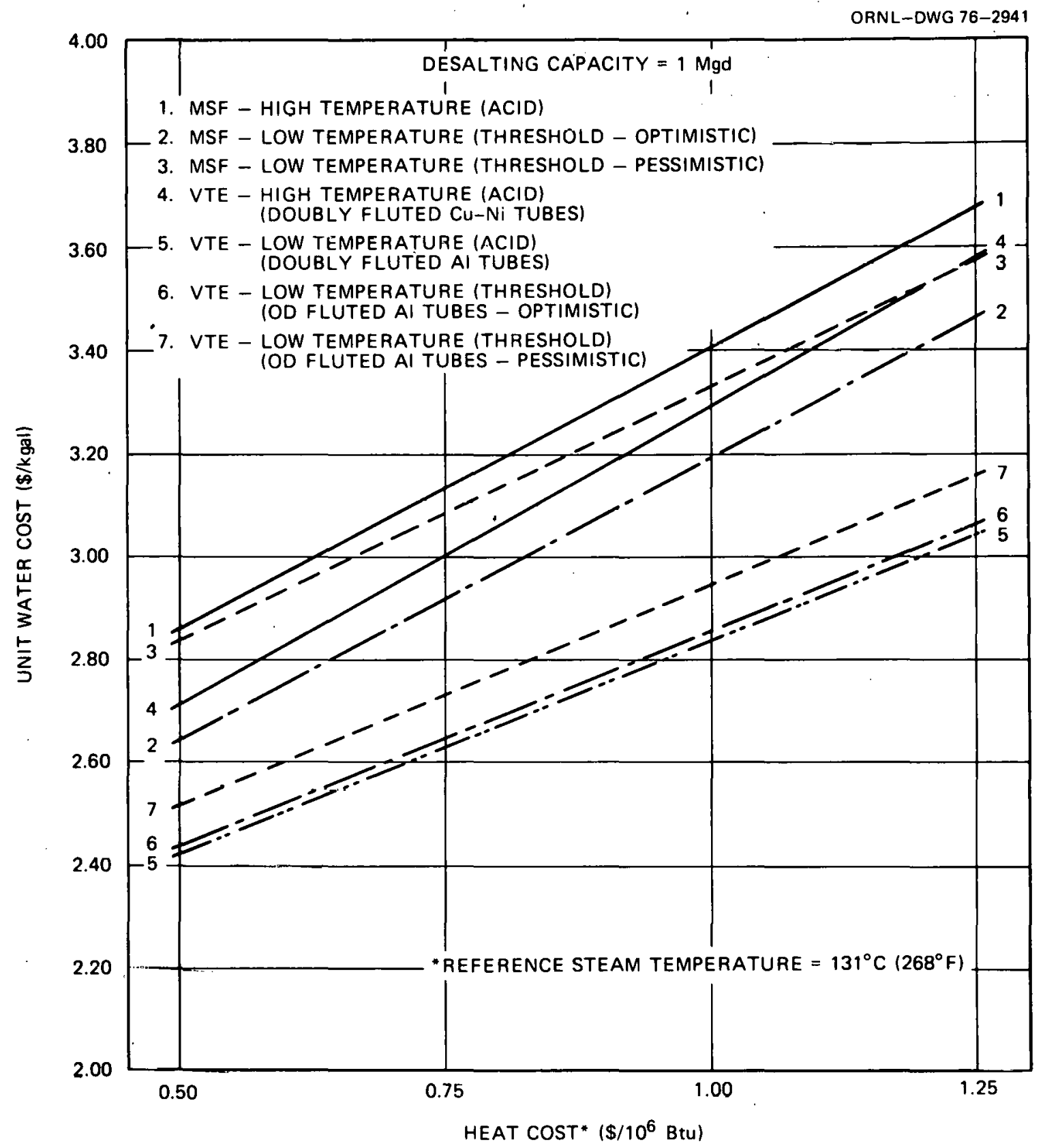

Fig. 6. Unit water cost vs heat cost. Comparison of 1 Mgd MSF and VTE dual-purpose plants. 
A detailed unit water cost breakdown of the optimized 100-Mgd desalting plants at reference energy costs is shown in Table 11.

Unit water costs versus performance ratio (MSF plant) and number of effects (VTE plant) are plotted in Figs. 7 and 8 for MSF and VTE plants, respectively. 
Table 11. Unit water cost breakdown of optimized (at reference energy cost) $100 \mathrm{Mgd}$ desalting plants

\begin{tabular}{|c|c|c|c|c|c|c|c|c|c|c|c|c|c|c|c|}
\hline & \multirow{4}{*}{$\begin{array}{c}\text { Process type } \\
\text { Pretreatment } \\
\begin{array}{c}\text { Design \& operational } \\
\text { assumptions }\end{array}\end{array}$} & \multicolumn{6}{|c|}{ MSF } & \multicolumn{8}{|c|}{ VTE } \\
\hline & & \multirow{2}{*}{\multicolumn{2}{|c|}{$\frac{\text { Acid }}{\text { Reference }}$}} & \multicolumn{4}{|c|}{ Threshold } & \multicolumn{4}{|c|}{ Acid } & \multicolumn{4}{|c|}{ Threshold } \\
\hline & & & & \multicolumn{2}{|c|}{ Optimistic } & \multicolumn{2}{|c|}{ Pessimistic } & \multicolumn{2}{|c|}{ Reference } & \multirow{2}{*}{$\begin{array}{l}\text { Reference } \\
\text { aluminum } \\
\begin{array}{c}\$ / 1000 \\
\text { gal }\end{array}\end{array}$} & \multirow{2}{*}{$\begin{array}{c}\begin{array}{c}\text { for } \\
\text { tubes }\end{array} \\
\%\end{array}$} & \multicolumn{2}{|c|}{ Optimistic } & \multicolumn{2}{|c|}{ Pessimistic } \\
\hline & & $\begin{array}{l}\$ / 1000 \\
\text { ga1 }\end{array}$ & $\%$ & $\begin{array}{l}\$ / 1000 \\
\text { gal }\end{array}$ & $\%$ & $\begin{array}{l}\$ / 1000 \\
\text { gal }\end{array}$ & $\%$ & $\begin{array}{l}\$ / 1000 \\
\text { gal }\end{array}$ & $\%$ & & & $\begin{array}{l}\$ i 1000 \\
\text { gal }\end{array}$ & $\%$ & $\begin{array}{l}\$ / 1000 \\
\text { gal }\end{array}$ & $\%$ \\
\hline Cost & components: & & & & & & & & & & & $\cdot$ & & & \\
\hline 1. & Capital $\cos t$ & 0.671 & 50.34 & 0.688 & 51.23 & 0.747 & 51.37 & 0.579 & 48.29 & 0.579 & 53.31 & 0.637 & 51.83 & 0.661 & 51.52 \\
\hline 2. & Retubing & & & & & & & 0.014 & 1.17 & 0.012 & 1.11 & 0.014 & 1.14 & 0.014 & 1.09 \\
\hline \multicolumn{16}{|c|}{ 3. Energy cost } \\
\hline & Process heat & 0.365 & 27.38 & 0.327 & 24.35 & 0.337 & 23.18 & 0.356 & 29.69 & 0.228 & 20.99 & 0.258 & 21.00 & 0.263 & 20.50 \\
\hline & Ejector stean & 0.008 & 0.60 & 0.016 & 1.19 & 0.016 & 1.10 & 0.007 & 0.58 & 0.007 & 0.65 & 0.016 & 1.30 & 0.016 & 1.25 \\
\hline & Electrical power & $\underline{0.132}$ & 9.90 & $\underline{0.147}$ & 10.94 & $\underline{0.165}$ & 11.35 & $\underline{0.110}$ & 9.18 & $\underline{0.121}$ & 11.14 & $\underline{0.146}$ & 11.87 & $\underline{0.150}$ & 11.69 \\
\hline & Total energy & 0.505 & 37.83 & 0.490 & 36.48 & 0.518 & 35.63 & 0.473 & 39.45 & 0.356 & 32.78 & 0.420 & 34.17 & 0.429 & 33.44 \\
\hline \multicolumn{16}{|c|}{$\begin{array}{l}\text { 4. Operation \& } \\
\text { maintenance }\end{array}$} \\
\hline & Staff & 0.040 & 3.00 & 0.036 & 2.68 & 0.040 & 2.75 & 0.040 & 3.34 & 0.040 & 3.68 & 0.036 & 2.93 & 0.040 & 3.12 \\
\hline & Supply \& materials & 0.040 & 3.00 & 0.033 & 2.46 & 0.036 & 2.48 & 0.034 & 2.83 & 0.034 & 3.13 & 0.030 & 2.44 & 0.031 & 2.41 \\
\hline & Chemicals & $\underline{0.077}$ & $5.7 \varepsilon$ & $\underline{0.096}$ & 7.15 & $\underline{0.113}$ & 7.77 & $\underline{0.059}$ & 4.92 & $\underline{0.065}$ & 5.99 & $\underline{0.092}$ & 7.49 & $\underline{0.108}$ & 8.42 \\
\hline & Total o\&l1 & 0.157 & $11.7 \varepsilon$ & 0.165 & 12.29 & 0.189 & 13.00 & 0.133 & 11.09 & 0.139 & 12.80 & 0.158 & 12.86 & .0 .179 & 13.95 \\
\hline & Total unit water cost & 1.333 & $100.0 \mathrm{C}$ & 1.343 & 100.00 & 1.454 & 100.00 & 1.199 & 100.00 & 1.086 & 100.00 & 1.229 & 100.00 & 1.283 & 100.00 \\
\hline
\end{tabular}




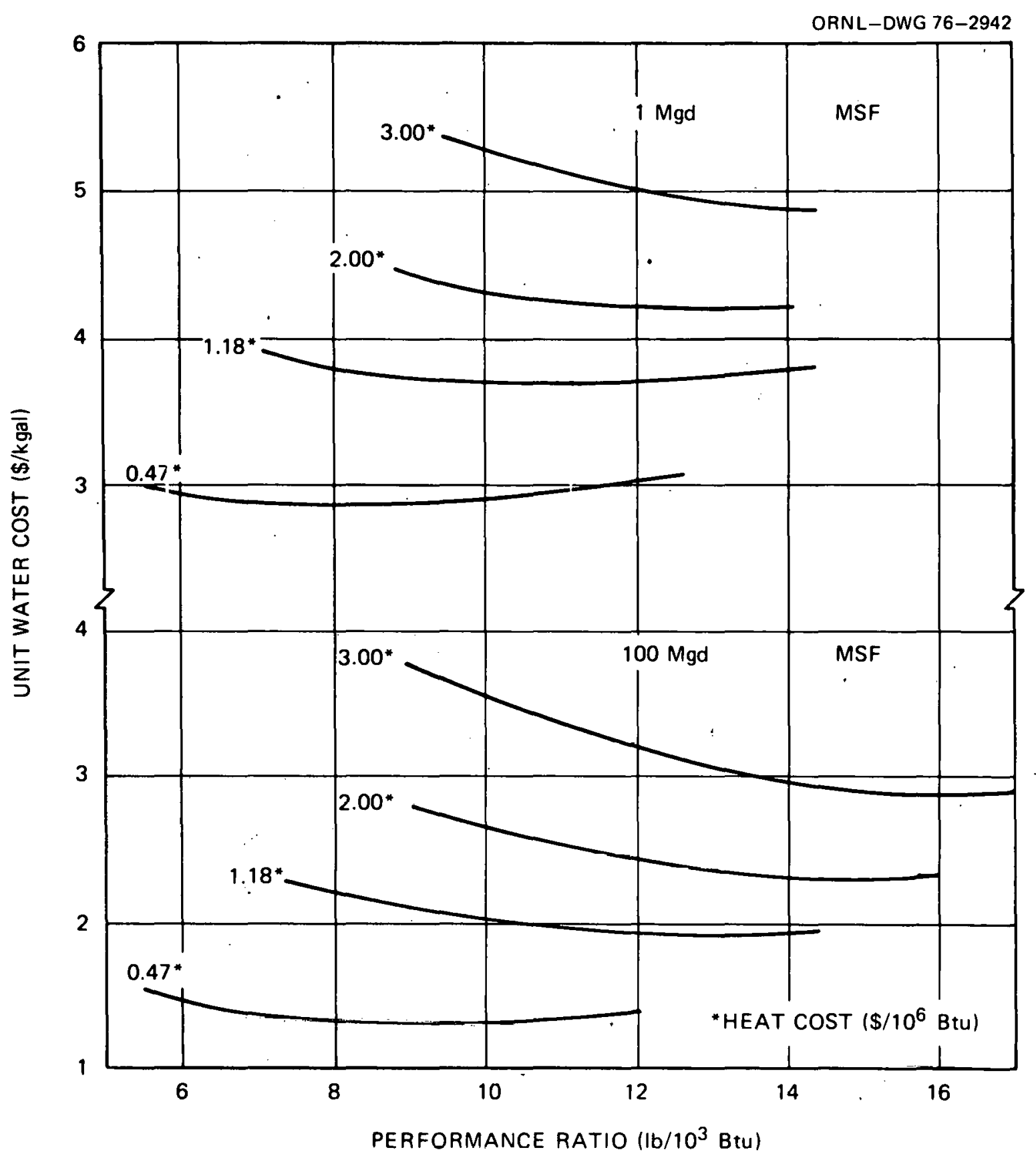

Fig. 7. Unit water cost vs performance ratio and heat cost from high temperature (acid) MSF plants. 


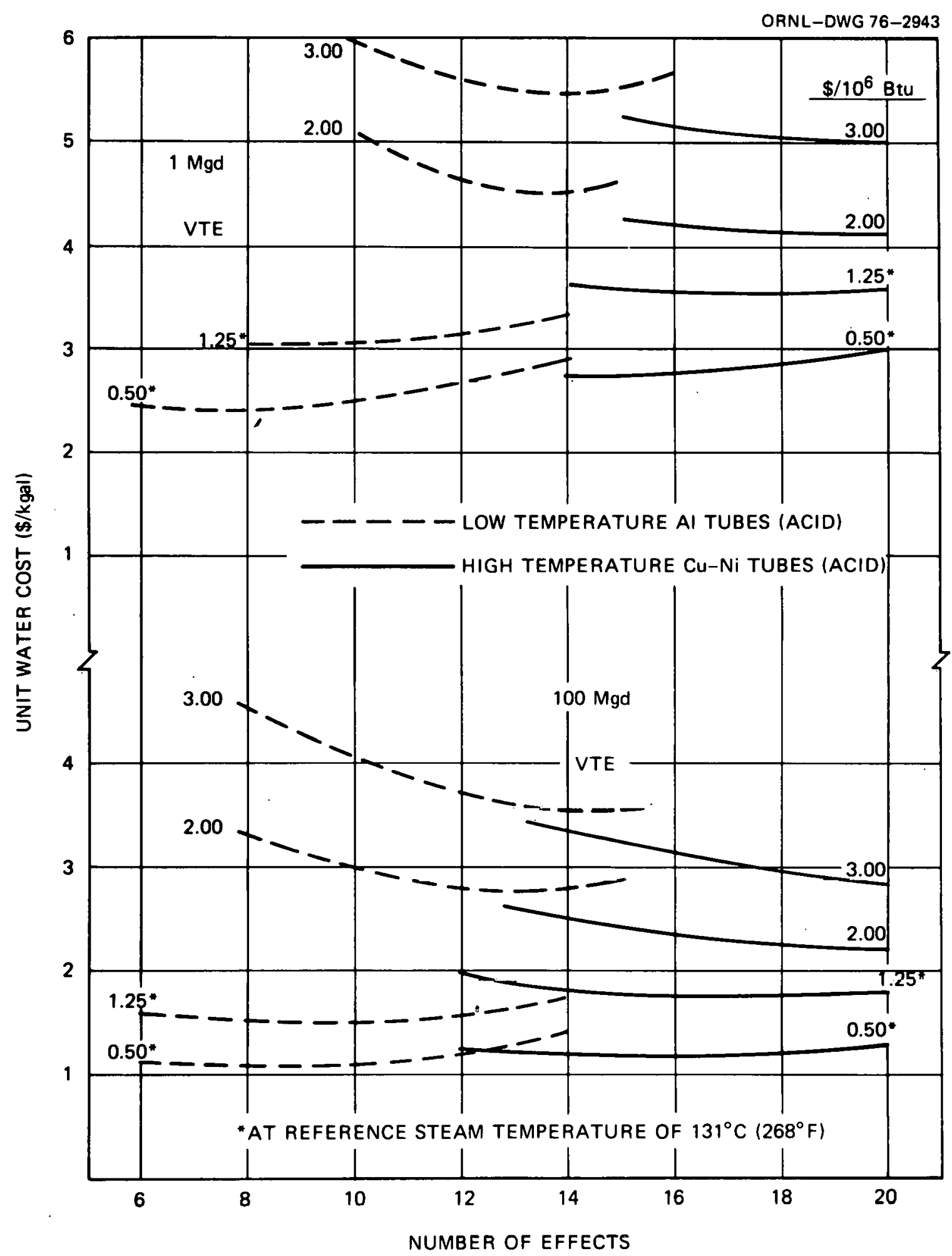

Fig. 8. Unit water cost vs number of VTE effects and heat cost from high (acid) and low (aluminum tubes - acid) temperature VTE plants. 


\section{ANALYSIS OF RESULTS}

\subsection{Range of Capital and Unit Water Costs}

The resulting capital costs for large desalting plants, based on current technology and optimized on the basis of relative low energy cost, obtained from large nuclear plants, range from $\$ 1.50$ to $\$ 2.00$ per gpd. These costs are about three times higher than the capital costs estimated 7 to 8 years ago for plants having similar performance ratios (11 to $14 \mathrm{lb} / 10^{3} \mathrm{Btu}$ ). In this time period plant equipment (except heat transfer tubing) and construction cost increased about $100 \%$, on the average. As heat transfer tubing costs were less affected, the average cost increase, caused by inflation of equipment cost, would have to be less than $100 \%$. The additional $100 \%$, or more, of increase in the total capital cost of large desalting plants is caused by two major factors: (a) the prevailing high cost of money and the continuous inflation which strongly affect the indirect capital costs; and, (b) the current observed tendency of the desalting plant manufacturers to apply more conservative design criteria regarding process equipment and construction materials. By far the larger of these two factors is due to (a). From Table 8, it can be seen that the total investment of 100-Mgd MSF plants is approximately $180 \%$ of the direct capital cost. This additional $80 \%$ is almost three times as much as the percentage for indirect cost plus contingency, applied in the cost estimation of ORNL's 250-Mgd MSF Conceptual Design ${ }^{3}$ in January 1969.

The resulting capital cost of small desalting plants in the 1-Mgd capacity range varied between $\$ 4$ to $\$ 6$ per gpd. The lower figure is representative for plants having low performance ratios and the higher figure for plants optimized for high energy costs. At a process steam cost of $\$ 3 / 10^{6} \mathrm{Btu}$, optimum performance ratios were found to be approximately 14 to $12 \mathrm{lb} / 1000 \mathrm{Btu}$ for high-temperature (acid) and low-temperature (threshold) MSF plants (see Table 3).

The resulting unit water costs ranged from $\sim \$ 1.20$ to $\$ 2.90 / \mathrm{kgal}$ and $\sim \$ 2.60$ to $\$ 6.00 / \mathrm{kgal}$ for large (100 Mgd) and small ( 1 to $2.5 \mathrm{Mgd}$ ) desalting plants, respectively. These wide ranges in costs emphasize the 
strong impact of energy prices on desalted water cost. From comparison of unit water cost breakdown illustrated in Fig. 9, it can be concluded that a sixfold increase in process steam cost increases the unit water cost by approximately 70 to $120 \%$. It can also be concluded that the threefold to fourfold increase in desalted water cost occurring in the last 2 to 3 years is only partially caused by the sharp rise in energy prices. The other factor contributing to the sharp cost increase, having almost the same impact as the rising energy prices, is obviously continuously rising capital cost and the prevailing high interest rates.

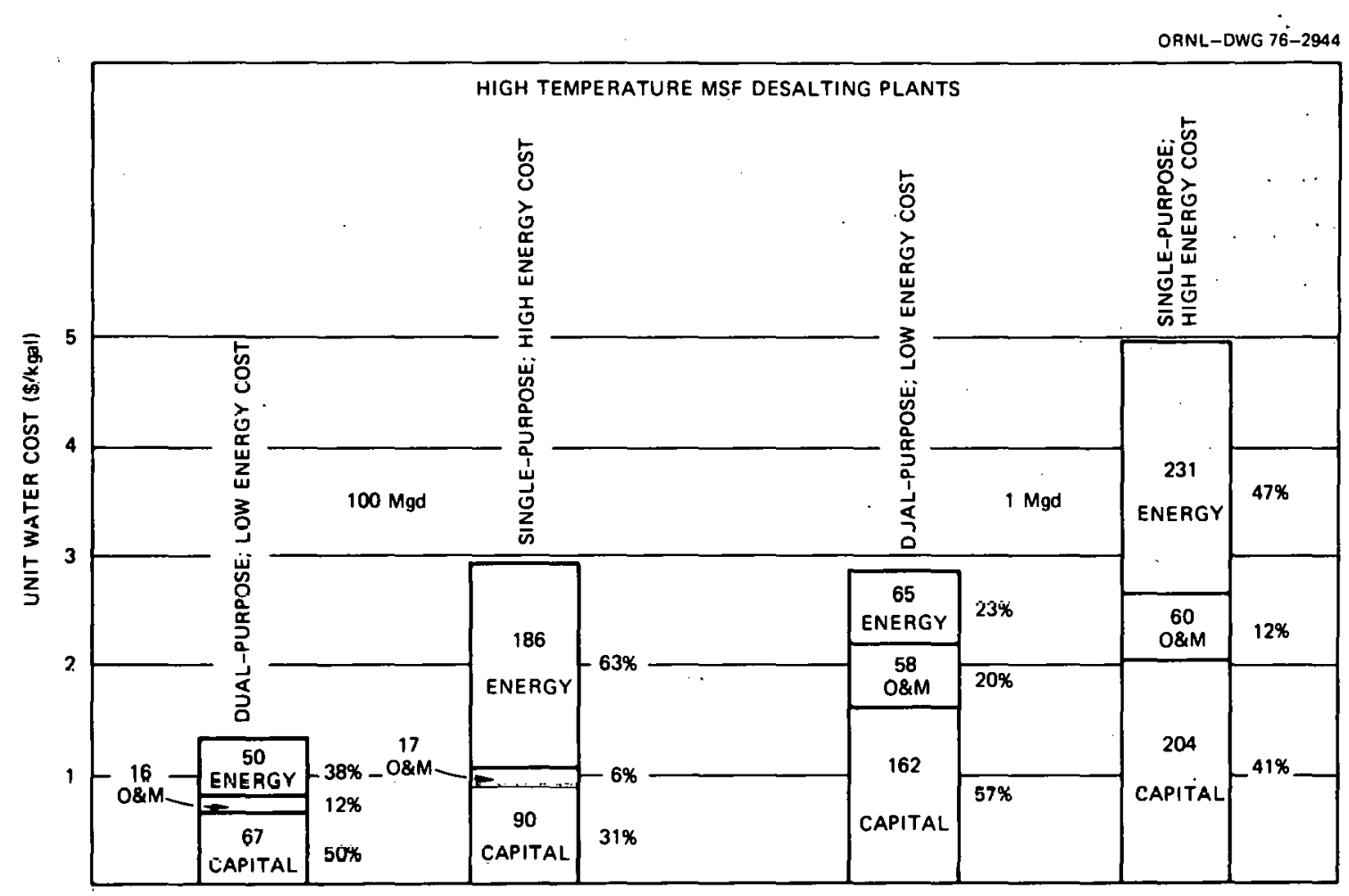

Fig. 9. Unit water cost breakdown vs energy cost and plant size. 


\subsection{Comparison Between High-Temperature MSF and VTE Plants}

For large plants the resulting capital costs of the optimized VTE plants (see Tables 7 and 8 ) were 13 to $15 \%$ lower than the MSF plants operating at the same temperature level. The corresponding performance ratios of the VTE and MSF plants were only slightly different so that the costs reflected the actual basic differences between these two concepts. These differences are well known and have been analyzed comprehensively in the past in numerous studies. For the design concepts based on current technology, the main characteristics of the optimized MSF and VTE designs can be seen from the resulting design data shown in Table 5. By comparing the breakdown of the capital costs, given in Table 8 , it can be seen that the greatest differences were obtained in the shell and foundation costs. This difference fully reflects the substantial lower required evaporator volume for the VTE. The other major basic difference that of the much lower total heat transfer surface - is partially offset by the higher unit surface cost of the enhanced surfaces and the higher tubesheet and tubing installation cost. The somewhat more complicated system of the VTE is reflected by the resulting higher cost of the valves and piping and the instrumentation cost components. The higher unit costs of the pumping units and the electrical equipment for the VTE is offset by the lower total pumping power.

The resulting unit water cost from large high-temperature VTE plants is approximately $10 \%$ lower than from the high-temperature acid-treated MSF plants (see Tables 10 and 11). This reduction in cost is obtained mainly due to the lower capital costs, the lower pumping power cost, and the lower chemical consumption cost.

For plants having small capacities ( 1.0 and $2.5 \mathrm{Mgd})$, the economic advantage of the VTE is considerably reduced, especially for plants optimized for high energy price levels (see Table 9). For very high energy cost $\left(\$ 3 / 10^{6} \mathrm{Btu}\right)$ the resulting cost from the VTE design was even slightly higher than for the MSF design. It is, however, emphasized that the VTE constructural design concept adopted, where the MSF preheater was integrally located in the same vessel under the VTE effects, is probably not well suited to the design requirements of plants having small 
capacities and operating with high performance ratios. This is mainly due to the relative short length of the vessel required to house the VTE effects and results in too small a preheater which affects the combined overall performance ratio of the VTE-MSF preheater system. However, the long-tube design adopted for the MSF plants is probably also not the best design concept for small plant sizes for which the cross-tube design might be considerably more economical. The results of the present investigation can therefore not be applied for the comparison between small MSF and VTE units.

\subsection{Comparison Between High- and Low-Temperature MSF Designs}

By comparing the unit water costs in Tables 9,10 , and 11 , it was concluded that low temperature plants, applying the threshold pretreatment method, might be economically attractive for small dual-purpose electric power-MSF desalting plants. For single-purpose plants the assumed potential cost savings could not outweigh the thermodynamic disadvantage of the low-temperature process, and the resulting unit water costs were considerably higher. The effect of energy cost and desalting plant size on the comparison between high- and low-temperature MSF plants, operating in a single or dual-purpose system; are shown in Fig. 10. From the comparison shown in Fig. 10, it can be seen that low-temperature nonacid treated plants could eventually be competitive for continuous rising energy cost, even for large plant capacities.

\subsection{Comparison Between High- and Low-Temperature VTE Designs}

As expected, the low-temperature aluminum tubing VTE design is only economically attractive for application in dual-purpose plants. The potential reduction in unit water costs (see. Tables 9,10 , and 11), when applying doubly fluted aluminum tubing, amounts to 10 to $15 \%$. The larger cost saving was obtained at the higher energy price level. The effect of reference heat cost and plant capacity on the comparison of high- and low-temperature designs are also illustrated in Fig. 11. 


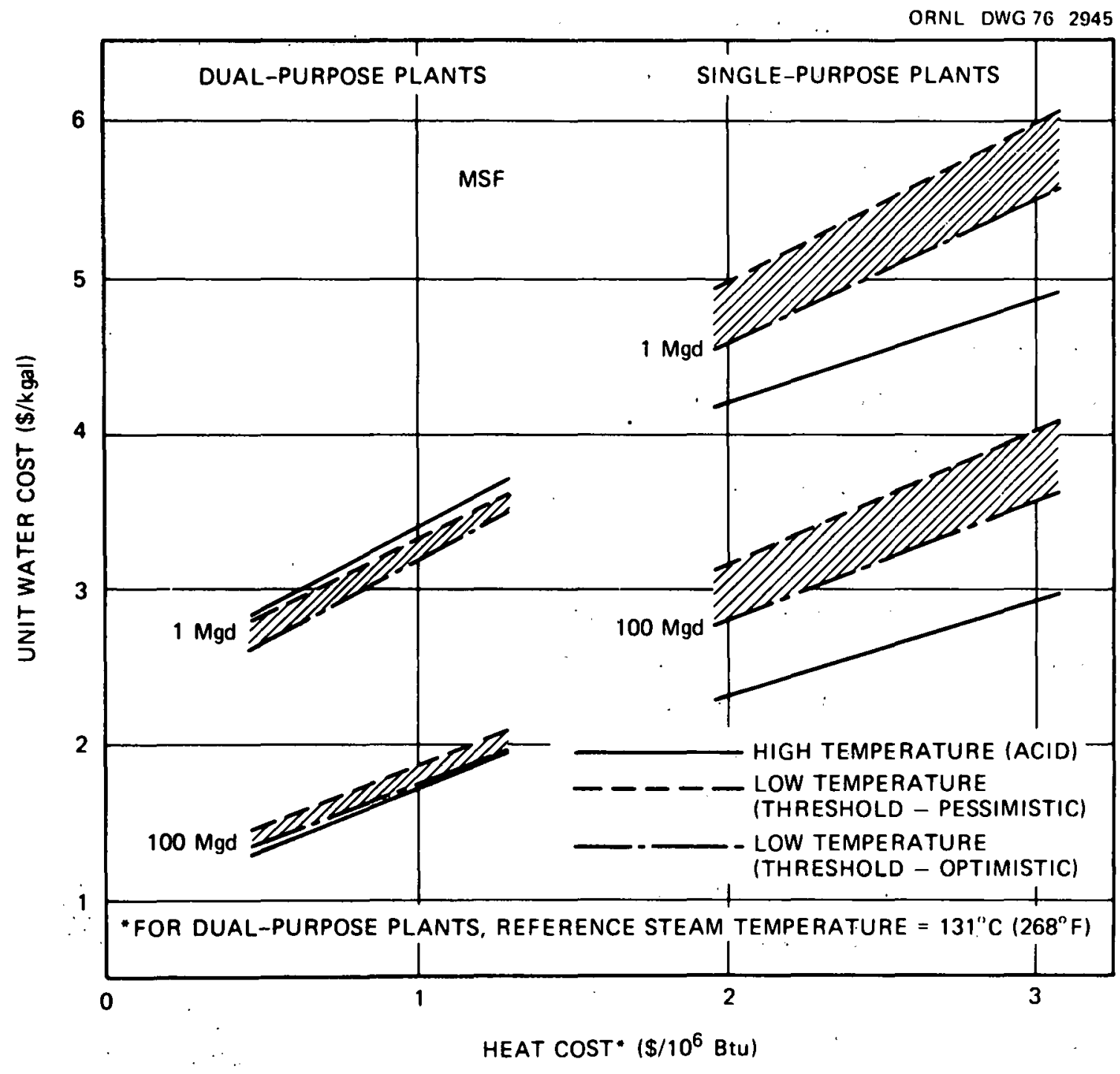

Fig. 10. Unit water cost from MSF plants vs heat cost and plant size.

The optimized doubly-fluted aluminum-tubed VTE designs have approximately the same capital costs (except for small capacities) as the high temperature designs, but, of course, for much lower performance ratio (PR). From the design data shown in Table 5, it can be seen that the lowtemperature design, for a 100-Mgd plant optimized at the reference energy price level, resulted in only seven effects $(P R=6.18)$, compared to 15 effects $(P R=11.00)$ for the high-temperature design. Even at that much lower performance ratio, the reduced heat cost at a temperature of 


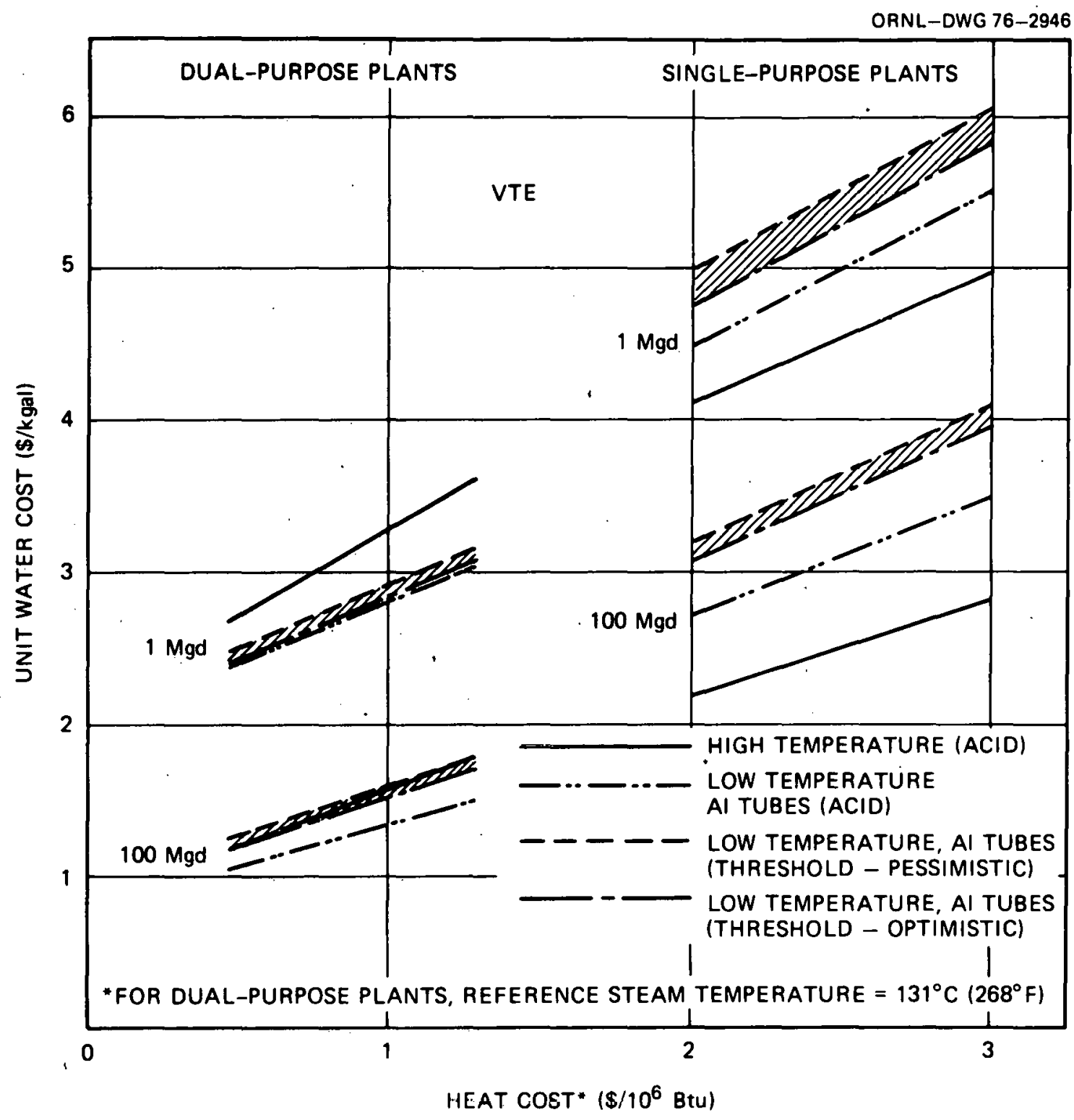

Fig. 11. Unit water cost from VTE plant vs heat cost and plant size.

$178^{\circ} \mathrm{F}$ more than outweighs the larger heat consumption, and the net effect is reduced process heat cost by about one third (see Table 11). The total energy cost was, however, less affected because of a somewhat higher electrical power cost.

The nonacid treated low-temperature designs have, obviously, considerably less potential benefits because of the basic assumption that a 
threshold pretreatment method could not be applied for doubly-fluted tubing. The much lower heat transfer coeffictent of tubes fluted on the condensing surface only also affects other design characteristics, such as plant dimensions (see Table 5), and therefore, increases the cap1tal cost substantially.

For large capacity plants and the reference energy cost level, the low-temperature designs applying threshold pretreatment were not found to be competitive with the high-temperature designs. Smaller plants are, however, much less affected by the reduced heat transfer coefficients and benefit more from the potential advantages of the threshold pretreatment. From the comparison shown in Fig. 11, it can be seen that for 1-Mgd plants, potential cost savings of the threshold low-temperature designs are not much lower than those from acid-treated low-temperature design. It can therefore be concluded that even for the case where an acid treatment might not be compatible with aluminum alloy tubing, the lowtemperature VTE would still be economically attractive for small capacity p.lants. For larger capacities this design would eventually be competitive for the case of high energy costs (see Fig. 11). 


\section{SENSITIVITY ANALYSIS}

\subsection{Introduction}

As far as possible, the present investigation was based on current technology and prevailing economic conditions, except for the low temperature VTE designs. The selection of construction materials, module and i train sizes, and other technological design parameters, as well as the economic ground rules, was therefore set accordingly. The only economic parameter varied, in the evaluation of the design concepts investigated, was the energy cost. Other economic or operational parameters, such as the interest rate or the plant operating factor, may vary with time and/or plant location. The effect of these parameters, as well as the effect of technological parameters, which might be eventually varied after some technological and/or materials market developments, were investigated with the aid of a brief sensitivity analysis.

\subsection{Effect of Technological Parameters}

The major technological design parameters affecting the capital and unit water costs were found to be, as expected, the evaporator shell and tubing material, and, for large capacity plants, the largest applicable independently operating train size, consisting of a multiple number of. modules. Several other much less significant design parameters include the tubing diameter and length, the brine flow per tray width (MSF), and the freeboard between the brine level and tube bundle (MSF).

The effect of the aforementioned technological design parameters was made on a 100-Mgd acid-treated MSF design optimized on the basis of the reference energy cost. The effects of module and train size on capital and unit water costs are shown in Fig. 12. From the results in Fig. 12, it is evident that module sizes larger than $12.5 \mathrm{Mgd}$ would not be economic in cases where a small number of trains is utilized for a $100-\mathrm{Mgd}$ design. Thus, in case of two $50 \mathrm{Mgd}$ trains, four $12.5 \mathrm{Mgd}$ modules per train are more economic than two $25-\mathrm{Mgd}$ modules or one 50-Mgd module. The effect of the other major design parameters, each varied independently 


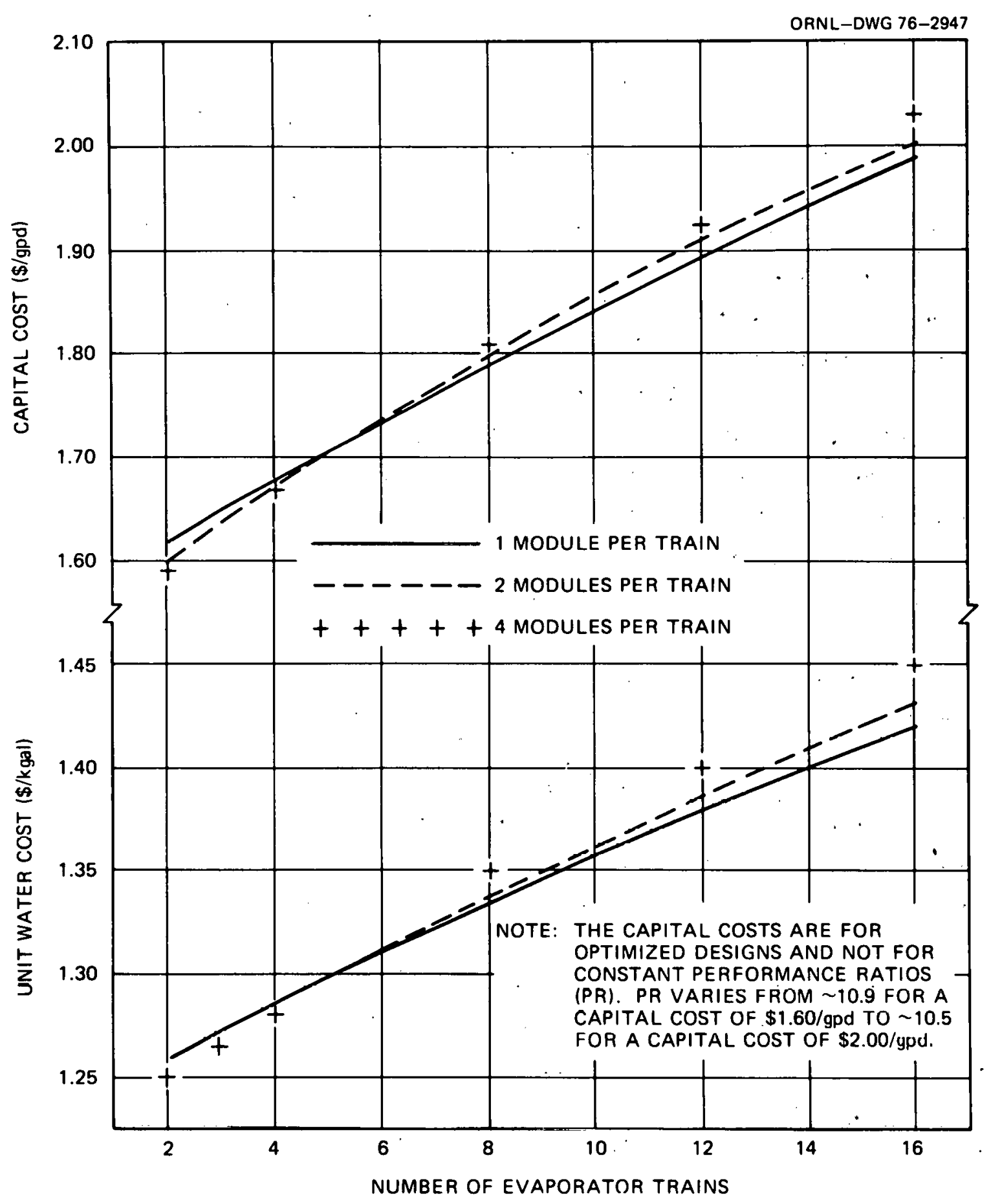

Fig. 12. Capital and unit water cost of a $100 \mathrm{Mgd}$ MSF plant vs number of evaporator trains. 
while all others were kept at their reference design values, are summarized in Table 12.

In the sensitivity analysis, aluminum-brass tubing was assumed to be $20 \%$ cheaper than $90-10 \mathrm{Cu}-\mathrm{Ni}$, and $5 / 8-\mathrm{in}$. tubing was assumed to be $5 \%$ more costly (per $f t^{2}$ ) than $3 / 4-i n$. tubing.

The fouling factor, which is mostly dependent on the pretreatment method and some operational factors, such as the tube cleaning frequency, may also be considered as a technological design parameter. Moreover, a low fouling factor yields a high heat transfer coefficient and therefore has a similar effect to that which could be obtained, eventually, by applying some kind of enhanced horizontal tubing, such as spirally indented tubing. Thus, by assuming a theoretical zero fouling factor, the heat transfer coefficient was increased by approximately $40 \%$ above the value obtained with the reference fouling factor of 0.0005 . The resulting saving (see Table 12) in unit water cost was $6 \%$.

The combined effect of varying several design parameters simultaneously and that of a set of extreme optimistic assumptions was also evaluated and shown in Table 12. The result of this evaluation may give some indication of the inherent development potential of the MSF desalting process.

The effect of a reduced fouling factor was also evaluated, mainly because its effect is equivalent to a higher heat transfer coefficient, which might eventually be obtained by applying some kind of enhanced horizontal tubing, such as spirally indented tubing.

From the results shown in Table 12 it is evident that the total development potential of the MSF process is an approximate $20 \%$ cost saving. It is, however, doubtful if all of the listed cost savings could be realized; and it is therefore more realistic to assume a potential cost saving of about $10 \%$.

\subsection{Effect of Economic Parameters}

The effect of changing the economic ground rules was investigated on four 100-Mgd design concepts optimized on the basis of the reference energy cost. The parameters changed were the interest rate, the plant 
Table 12. Effect of technological parameters on the unit water cost from a $100 \mathrm{Mgd}$ high-temperature acid treated MSF plant (unit water cost from reference design $=\$ 1.33 / \mathrm{kgal}$ )

\begin{tabular}{cccc}
\hline $\begin{array}{c}\text { Technological design } \\
\text { parameters varied }\end{array}$ & Cost increase & \multicolumn{2}{c}{ Cost saving } \\
\cline { 2 - 5 } & $\$ / 1000 \mathrm{gal} \%$ & $\$ 11000 \mathrm{gal} \%$ \\
\hline
\end{tabular}

1. Train and module size:
a. 12 trains and modules
$0.06 \quad 4.5$ (instead 8)

b. 4 trains and 8 modules

c. 2 trains and 8 modules

2. Aluminum-brass tubing (instead $90-10 \mathrm{Cu}-\mathrm{Ni}$ )

3. 5/8 in. diameter tubing (instead $3 / 4$ in.)

$\begin{array}{ll}0.05 & 3.8 \\ 0.08 & 6.0 \\ 0.03 & 2.3 \\ 0.02 & 1.5\end{array}$

4. Tubing length:
a. $\sim 200 \mathrm{ft}$ (instead $\sim 70 \mathrm{ft}$ )
0.02
1.5
b. $\sim 100 \mathrm{ft}$
0.01
0.8 .
c. $\sim 50 \mathrm{ft}$
$0.01 \quad 0.8$

5. Brine tray flow at the cold end:
a. $4 \times 10^{6} \mathrm{lb} / \mathrm{hr} \cdot \mathrm{ft}($ width)
(instead $.8 \times 10^{6}$
0.12
9.0
b. $1.2 \times 10^{6} \mathrm{lb} / \mathrm{hr} \cdot \mathrm{ft}$ (width)
0.04
3.0

6. Freeboard between brine level and tube bundle:
a. $7.5 \mathrm{ft}$ (instead $5.75 \mathrm{ft}$ )
0.01
0.8
b. $4.0 \mathrm{ft}$
0.01
0.8

7. Fouling factor (recovery section):
a. .0008 (instead .0005)
0.05
3.8
b. .0002
c. Zero fouling
0.04
3.0
0.08
6.0
8. Combined effect of $1 \mathrm{c}$ and 2
0.13
19.8
9. Combined effect of $1 c, 5,6 b$,
0.19
14.3
$7 b$ and $8 b$
10. Combined effect of $1 c, 3,4$,
0.22
16.5
$5 a, 6 b, 7 b$ and $8 b$
11. Combined effect of $1 c, 2,3,4$, $5 a, 6 b, 7 b$ and $8 c$
0.28
21.1 
operating factor, the total capital cost, the total energy cost, and the total operating and maintenance cost (less energy cost). The effect of changing the reference values of these parameters on the unit water cost is summarized in Table 13.

The results of the sensitivity analysis shown in Table 13 indicate that at more favorable economic conditions, including a $20 \%$ decrease in interest rate, total investment and operating (excluding energy) cost, and a higher plant operating factor ( $90 \%$ instead of $85 \%$ ), a cost saving of about 20 to $25 \%$ could be realized. On the other hand, less favorable economic conditions, including a $20 \%$ increase in interest rate, total investment and operating cost, a lower plant operating factor (75\% instead of $85 \%$ ), and a $50 \%$ increase in energy cost would, affect the unit water cost by about 50 to $55 \%$. 
Table 13. Effect of economic parameters on the unit water cost from 100 Mgd desalting plants

\begin{tabular}{|c|c|c|c|c|c|c|c|c|}
\hline \multirow{3}{*}{$\begin{array}{c}\text { Process type } \\
\text { Design concept } \\
\begin{array}{c}\text { Reference unit } \\
\text { water cost }\end{array}\end{array}$} & \multicolumn{4}{|c|}{ MSF } & \multicolumn{4}{|c|}{ VTE } \\
\hline & \multicolumn{2}{|c|}{$\begin{array}{l}\text { High-temperature } \\
\text { Acid treated }\end{array}$} & \multicolumn{2}{|c|}{$\begin{array}{l}\text { Low-temperature } \\
\text { Threshold* }\end{array}$} & \multicolumn{2}{|c|}{$\begin{array}{l}\text { High-temperature } \\
\text { AcId; Cu-Ni tubes }\end{array}$} & \multicolumn{2}{|c|}{$\begin{array}{c}\text { Low-temperature } \\
\text { Ac1d; aluminum tubes }\end{array}$} \\
\hline & 1.33 & 100.0 & 1.34 & 100.0 & 1.20 & 100.0 & 1.09 & 100.0 \\
\hline & $\$ / 1000 \mathrm{gal}$ & $\%$ & $\$ / 1000 \mathrm{gal}$ & $\%$ & $\$ / 1000 \mathrm{gal}$ & $\%$ & $\$ / 1000 \mathrm{gal}$ & $\%$ \\
\hline
\end{tabular}

1. Interest rate:

\section{Increased from} $10 \%$ to $12 \%$

Decreased from $10 \%$ to $8 \%$

2. Plant operating factor:

Increased irom $85 \%$ to $90 \%$

Decreased from $85 \%$ to $75 \%$

3. $20 \%$ change in capital cost

$\begin{array}{llllllll}+0.13 & +9.8 & +0.13 & +9.7 & +0.12 & +10.0 & +0.12 & +11.0 \\ -0.12 & -9.0 & -0.12 & -9.0 & -0.11 & -9.2 & -0.11 & -10.1\end{array}$

$0 \%$ increase in total energy cost

5. $20 \%$ change in operation and

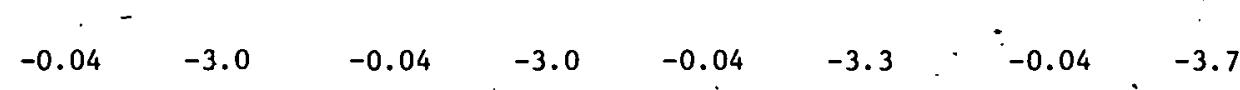

$+0.10$

$+7.5$

$+0.10$

$+7.5$

$+0.09$

$+7.5$

$+0.09$

$+8.3$

$+0.13$

$\pm 9.8$

$\pm 0.14$

$\pm 10.4$

$\pm 0.12$

$\pm 10.0$

$\pm 0.12$

$\pm 11.0$

$+0.25$

$+18.8$

$+0.25$

$+18.7$

$+0.24$

$+20.0$

$+0.18:+16.5$

$\pm 0.03$

$\pm 2.3 \pm 0.03$

$\pm 2.2 \pm 0.03$

$\pm 2.5$

$\pm 0.03$

$\pm 2.8$

6. Combined effect of all increasing

$+0.73$

$+55.0$

$+0.71$

$+52.9$

$+0.63:+52 . \overline{5}$

$+0.57+52.3$

cost factors

7. Combined effect of

$-0.29$

$-21.8$

$-0.30$

$-22.4$

$-0.27-22.5 \therefore-0.27-24.8$.

all decreasing cost factors

*Optimistic assumptions.

**Excluding energy cost. 


\section{REFERENCES}

1. W. G. S. Fort, "Computer Codes for Office of Saline Water Program Analysis, Part V: MSF-21: A Fortran Code for the Rapid Calculation or Optimization of Multistage Flash (MSF) Desalination Plants," ORNL-TM-3535, February 1972.

2. W. G. S. Fort and J. V. Wilson, Ibid., Part VI: VTE-21: A Fortran Code for the Rapid Calculation or Optimization of Vertical Tube Evaporator (VTE) Desalination Plants, ORNL-TM-3535 (to be published).

3. "Study of 250 MGD Multistage Flash Distillation Plant with Two Level Brine Flow," Part One: S. J. Senatore, and J. A. Smith, "Design and Cost Estimate," Part Two: Bechtel Corporation, "Preliminary Engineering Analysis and Capital Cost Estimate," ORNL-4214, January 1969.

4. E. C. Hise and S. A. Thompson, "Conceptual Design Study of a 250 Mi1lion Gallons per Day Combined Vertical Tube - Flash Evaporator Desalination Plant," ORNL-4260, August 1969.

5. P. Glueckstern, J. V. Wilson, and S. A. Reed, "Design and Cost Modification of ORNL's Computer Programs MSF-21 and VTE-21 for Evaluation of Multistage Flash and Vertical Tube Evaporators," ORNL-TM-5230, June 1976.

6. J. E. Jones Jr., "A Dua1-Purpose Nuclear Desalting Plant Using a LowTemperature Evaporator," ORNL-TM-4289, September 1973.

7. L. G. Alexander and H. W. Hoffman, "Performance Characteristics of Advanced Evaporator Tubes for Long-Tube Vertical Evaporators," OSW Report No. 644, January 1971.

8. W. G. S. Fort, S. H. Moore, and J. V. Wilson, "Computer Codes for Office of Saline Water Program Analysis. Part III: Programs and Subprograms Common to Several Desalination Processes, Including Code PROC21, ORNL-TM-3535, January 1973. 


\section{THIS PAGE}

\section{WAS INTENTIONALLY \\ LEFT BLANK}


ORNL/TM-5232

\section{Internal Distribution}

1. T. D. Anderson

2. S. J. Ball

3. D. F. Cope

4. W. B. Cottre11

5. F. L. Culler

6. G. G. Fee

7. M. J. Goglia

8. R. F. Hibbs

9. R. E. MacPherson

10. W. J. McCarthy, Jr.

11. J. W. Michel

12. J. S. Johnson

13. J. E. Jones

14. H. Postma
15-39. S. A. Reed

40. M. W. Rosenthal

41. M. R. Sheldon

42. M. J. Skinner

43. I. Spiewak

44. J. J. Taylor

45. D. B. Trauger

46. W. J. Wilcox

47-51. J. V. Wilson

52-53. Central Research Library

54. Document Reference Section

55-57. Laboratory Records Department

58. Laboratory Records, RC

\section{External Distribution}

59-63. Pinhas Glueckstern, Desalting Dept., Mekoroth Water Co., . 9 Lincoln Street, Tel Aviv, Israel.

64-68. W. F. Savage, Advanced Concepts Evaluation Branch, U.S. Energy Research and Development Administration, Washington, D.C. 20545

69-70. Director, Division of Nuclear Research and Applications, ERDA, Washington, D.C. 20545

71. Director, Reactor Division, ERDA, ORO

72. Research and Technical Support Division, ERDA, ORO

73-99. Technical Information Center, ERDA

100. G. H. Corey, 6600 West 13th Ave., Denver, Colorado 80214 